\title{
The role of standing dead Spartina alterniflora and benthic microalgae in salt marsh food webs: considerations based on multiple stable isotope analysis
}

\author{
C. A. Currin ${ }^{1}$, S. Y. Newell ${ }^{2}$, H. W. Paerl ${ }^{3}$ \\ ${ }^{1}$ National Marine Fisheries Service, Beaufort Laboratory, Beaufort, North Carolina 28516, USA \\ ${ }^{2}$ Marine Institute, University of Georgia, Sapelo Island, Georgia 31327, USA \\ ${ }^{3}$ Institute of Marine Sciences, University oi North Carolina, Morehead City, North Carolina 28557, USA
}

\begin{abstract}
The stable isotope compositions (C, N, and S) of live, senescent, and standing dead Spartina alterniflora were compared in order to determine the effects of aerial decomposition on the isotopic signature of aboveground $S$. alterniflora tissue entering the food chain. Aerial decomposition of aboveground S. alterniflora resulted in a 6 to $18 \%$ increase in $\delta^{34} \mathrm{~S}$, and a 2 to $3 \%$ decrease in $\delta^{15} \mathrm{~N}$ values; $\delta^{13} \mathrm{C}$ values were unchanged. We describe mechanisms whereby the activity of fungi and epiphytic nicroorganisms may contribute to the observed shifts in $\delta^{34} S$ and $\delta^{15} \mathrm{~N}$, respectively. The $\delta^{13} \mathrm{C}$ value of salt marsh benthic and epiphytic microalgae ranged from $-13.0 \%$ in summer to $-17.6 \%$ in early spring. Average $\delta^{15} \mathrm{~N}$ values of microalgae and standing dead S. alterniflora were -0.3 and $1.7 \%$, respectively, reflecting the activity of $\mathrm{N}_{2}$-fixing microorganisms. The $\delta^{15} \mathrm{~N}$ values for omnivorous and herbivorous salt marsh macrofauna ranged between 7.5 and $2.2 \%$, and for predatory Fundulus spp. $\delta^{15} \mathrm{~N}$ averaged $9.2 \%$. Given a presumptive $+3 \%$ trophic shift in $\mathrm{N}$ assimilation, these results suggest that $\mathrm{N}_{2}$-fixing microorganisms associated with microalgal communities were an important source of $\mathrm{N}$ to salt marsh consumers. The $\delta^{13} \mathrm{C}, \delta^{1 \cdot} \mathrm{N}$, and $\delta^{34} \mathrm{~S}$ values of primary producers were compared to the values of the following consumers: Fundulus spp., Uca spp., Ilyanassa obsoleta, and Littoraria irrorata. $\delta^{13} \mathrm{C}$ vs $\delta^{15} \mathrm{~N}$ and $\delta^{13} \mathrm{C}$ vs $\delta^{34} \mathrm{~S}$ dual isotope plots demonstrated that microalgae and standing dead S. alterniflora are important food resources in the North Carolina (USA) marshes we sampled. In addition, a compilation of literature values suggests that this is true in salt marshes throughout the East and Gulf coasts of North America. Future isotope studies of marsh food webs should include detrital Spartina spp. material in analyses of trophic structure.
\end{abstract}

KEY WORDS: Spartina alterniflora $\cdot$ Benthic microalgae $\cdot$ Stable isotopes Salt marsh Food web

\section{INTRODUCTION}

Analysis of the natural abundance of the stable isotopes of $\mathrm{C}, \mathrm{N}$, and $\mathrm{S}$ has been employed in estuarine ecosystems to trace the flow of primary production through the food web (see Fry \& Sherr 1984 for a review, Peterson et al. 1986, Peterson \& Howarth 1987 , Sullivan \& Moncreiff 1990). The strength of this approach is that an integrated measure of assimilated food source(s) can be made, and the relative contribution of food sources may be estimated by isotope mass balance when each has a unique isotopic signature.
Using stable C isotope analysis in a Georgia (USA) salt marsh, Haines (1976) concluded that while Spartina alterniflora Loisel. detritus contributed relatively little to estuarine suspended particulate organic carbon, $S$. alterniflora appeared to be an important food resource for insects grazing on live vegetation, and an important part of the diet of marsh snails (Haines \& Montague 1979). Mud snails, crabs, and filter feeders had $C$ isotopic signatures more suggestive of an algal-based diet (Haines \& Montague 1979). However, conclusions based solely on $\mathrm{C}$ isotopic values are equivocal because of the difficulty in distinguishing food 
resources with overlapping $\delta^{13} \mathrm{C}$ values (Haines \& Montague 1979, Schwinghamer et al. 1983). Later studies have applied a multiple stable isotope approach, utilizing $C, N$, and $S$ stable isotopes to help distinguish potential food resources. In a Massachusetts (USA) salt marsh, Peterson et al. (1986) concluded that S. alterniflora was an important component in the diets of the marsh mud snail Ilynassa (Nassarius) obsoleta (Say) and the killifish Fundulus heteroclitus (L.), while filter feeders relied more heavily on phytoplankton/detritus mixtures. Peterson \& Howarth (1987) also used a multiple stable isotope approach to re-examine food webs in the Georgia salt marsh earlier described by Haines and coworkers (Haines 1976, Haines \& Montague 1979). They concluded that the majority of fauna appeared to have a mixed diet of S. alterniflora and microalgae (pelagic and benthic). Most recently, a multiple stable isotope study of food webs in a Mississippi (USA) salt marsh concluded that edaphic algae were more important than S. alterniflora (Sullivan \& Moncreiff 1990).

The basis for the use of stable isotope analysis in food web studies is that organisms retain the stable isotope signals of the foods they assimilate (i.e. 'they are what they eat'), a phenomenon demonstrated conclusively by DeNiro \& Epstein $(1978,1981)$. However, the success of this approach is predicated upon the ability to distinguish the food resources isotopically. In addition, there can be seasonal and biochemical variations in the isotopic signature of plant and animal tissue (DeNiro \& Epstein 1978, 1981, Cifuentes et al. 1988, Fry \& Wainright 1991, Fogel et al. 1992, Simenstad et al. 1993), uncertainty in the isotopic shift between trophic levels (Fry \& Sherr 1984, Peterson et al. 1986, Peterson \& Howarth 1987), difficulty in obtaining an effective separation of microscopic algae from sediment and detrital particles (Schwinghamer et al. 1983, Hamilton et al. 1992), and decomposition effects on the isotopic signature of detritus (Benner et al. 1987).

In an examination of salt marsh food webs, it is important to note that it is mostly Spartina alterniflora detritus, and not living tissue, that enters the food web. The effects of diagenesis and decomposition on the $C$ isotopic signature of $S$. alterniflora have been examined in several studies (Haines \& Montague 1979, Benner et al. 1987, Ember et al. 1987, Fogel et al. 1989). Lignin is depleted in $\delta^{13} \mathrm{C}$ by 2 to $6 \%$ relative to whole plant material (Benner et al. 1987). Since lignin constitutes a greater portion of detrital $S$. alterniflora than living S. alterniflora (Wilson et al. 1986), detrital S. alterniflora should have a more negative (lighter) $\delta^{13} \mathrm{C}$ value than living tissue. Litterbag studies (Benner et al. 1987, Ember et al. 1987. Haddad et al. 1992) and analysis of sedimentary S. alterniflora detritus (Schwinghamer et al. 1983, Couch 1989, Fogel et al. 1989) have demonstrated that $S$. alterniflora decomposing in sediments does have a lighter $C$ isotopic value than living tissue, although the observed shift is typically $2 \%$ or less. However, the majority of $S$ alterniflora aboveground-biomass decomposes aerially, rather than in a submerged state (Newell \& Fallon 1989), and decomposition studies based on ground, dried, and/or buried fresh $S$. alterniflora do not reflect naturally occurring decomposition processes (Newell 1993). In particular, fungi play an important role in standing dead $S$. alterniflora decomposition, and are largely absent from submerged or sedimentary $S$. alterniflora detritus (Newell \& Fallon 1989). There are few published reports of the $\delta^{13} \mathrm{C}$ value of standing dead $S$. alterniflora (Haines 1976, Schwinghamer et al. 1983, Couch 1989\}, and the data suggest very little change in the stable C isotope ratio.

The effect of decomposition on the $\delta^{15} \mathrm{~N}$ and $\delta^{34} \mathrm{~S}$ values of Spartina alterniflora has not been examined, although there are anecdotal data in the literature. Couch (1989) reports that standing dead $S$. alterniflora has a lighter $\delta^{15} \mathrm{~N}$ than live $S$. alterniflora. Peterson et al. (1986) report a heavier $\delta^{34} \mathrm{~S}$ value for standing dead $S$. alterniflora relative to live plants in the Great Sippiwisset marsh (Massachusetts), but attribute it to changes in porewater sulfate $\delta^{34} \mathrm{~S}$, rather than effects of decomposition. Perhaps because of the scanty data available for $S$. alterniflora detritus, examinations of salt marsh food webs using a multiple stable isotope approach have utilized $\delta^{15} \mathrm{~N}$ and $\delta^{34} \mathrm{~S}$ values of living S. alterniflora in their analyses (Peterson et al. 1986, Peterson \& Howarth 1987, Sullivan \& Moncreiff 1990).

The contribution of benthic microalgae to salt marsh primary production has been the subject of several recent studies (Sullivan \& Moncreiff 1988a, Pinckney \& Zingmark 1993), and it appears that microalgal production represents at least $40 \%$ of the aboveground primary production of Spartina alterniflora in U.S. East Coast marshes, and possibly more in West Coast marshes (Zedler 1980). This production turns over more rapidly than S. alterniflora biomass, and has long been thought to be an important component of marsh food webs (Pomeroy et al. 1981). Despite this, benthic microalgae have received less attention than S. alterniflora and upland plants in most stable isotope analyses of marsh food webs; previous to this study, to our knowledge, there were 8 published reports of isotopic analysis of salt marsh microalgae compared to over 20 published reports of isotopic analysis of $S$. alterniflora (see Table 3 and references therein). Part of this discrepancy is due to collection difficulties in either obtaining sufficient microalgal biomass for mass spectroscopy analysis, or obtaining a sample free from contaminating sediment and detritus (Schwinghamer et al. 1983, Sullivan \& Moncreiff 1990, Hamilton et 
al. 1992). Exacerbating the problem of few replicate analyses is the potential for large fluctuations in algal $\delta^{13} \mathrm{C}$ and $\delta^{15} \mathrm{~N}$ values as a result of dissolved inorganic $\mathrm{C}$ limitation and intense nutrient cycling (Cifuentes et al. 1989, Fry \& Wainwright 1991, Fogel et al. 1992, Johnston \& Raven 1992, Simenstad et al. 1993). However, the potential for spatial and seasonal variations in estuarine benthic microalgal isotopic values has received little attention (Schwinghamer et al. 1983, Fry \& Sherr 1984, Couch 1989). Nevertheless, several investigations utilizing stable isotopes have demonstrated the potential for benthic microalgae to play an important role in salt marsh food webs (Fry \& Sherr 1984, Peterson \& Howarth 1987, Sullivan \& Moncreiff 1990).

This paper describes shifts in the $\delta^{15} \mathrm{~N}$ and $\delta^{34} \mathrm{~S}$ values of live and standing dead Spartina alterniflora. We identify mechanisms derived from parallel studies (Newell et al. 1992, Currin 1994, Currin et al. in press) which may be responsible for the observed isotopic shift in standing dead tissue. The stable isotopic signature of a variety of other estuarine primary producers (benthic and epiphytic microalgae, phytoplankton, benthic macroalgae) and consumers were determined in order to assess the role of standing dead $S$. alterniflora and benthic microalgae in salt marsh food webs.

\section{MATERIALS AND METHODS}

Study area. Samples for stable isotope analysis were collected from a natural (NAT) and a transplanted (TPL) Spartina alterniflora marsh located in the Newport River Estuary, ca $5 \mathrm{~km}$ from the Beaufort Inlet, North Carolina, USA. Details of the location and a physical description of this area, known as the Port Marsh, are in Currin et al. (in press). Briefly, the transplanted marsh was planted with wild-stock $S$. alterniflora in June 1990, on dredged material graded to intertidal elevation. At the time when this study began in summer 1992, canopy height $\left(X_{\text {NAT }}=130 \mathrm{~cm}\right.$, $\left.x_{\text {TPL }}=90 \mathrm{~cm}\right)$ and stem density $\left(x_{\text {NAT }}=260 \mathrm{~m}^{-2}\right.$, $\left.x_{\text {TPL }}=100 \mathrm{~m}^{-2}\right)$ in the transplanted marsh remained less than that in the adjacent natural marsh (S. Broome pers. comm.). Additionally, sediments in the natural marsh retained a higher organic matter content and greater silt-clay content than transplanted marsh sediments (Currin et al. in press).

Sample collection. Spartina alterniflora samples were collected in June, July, September, and November 1992, and in April 1993. Tissue described as live tissue was green, senescent tissue was yellow, and standing dead material was brown. Each analysis represented a subsample from a pooled sample of 10 to 20 plants. Unless otherwise noted, live and senescent
S. alterniflora included stem, leaf blades, and leaf sheaths. Standing dead tissue was predominantly stem and sheath material. When present, epiphytes were removed by scraping with a razor blade. S. alterniflora samples for $\mathrm{C}$ and $\mathrm{N}$ analysis were acidified in $1 \mathrm{~N} \mathrm{HCl}$ until all bubbling ceased, then washed 4 times in distilled water, dried, and ground through a no. 40 mesh screen in a Wiley mill. $S$. alterniflora tissue for $\mathrm{S}$ analysis was treated as above but without the acid wash. Samples were stored at $70^{\circ} \mathrm{C}$.

Fine, suspended particulate matter was collected in July 1992 on a flood tide at the mouth of a $1 \mathrm{~m}$ deep tidal creek in the transplanted marsh. Samples from the top $10 \mathrm{~cm}$ of the water column were collected with a $500 \mathrm{ml}$ plankton bottle with a $20 \mu \mathrm{m}$ Nitex screen, returned to the laboratory, allowed to settle for $10 \mathrm{~min}$, and the supernatant filtered through an ashed What man GF/C filter. Filters for $\mathrm{C}$ and $\mathrm{N}$ analysis were washed with $1 \mathrm{~N} \mathrm{HCl}$, rinsed 4 times with distilled water, and dried at $70^{\circ} \mathrm{C}$.

Salt marsh sediment samples were collected from the transplanted marsh in April 1993 and from the natural marsh in July 1992 and April 1993. In the natural marsh, the top $1 \mathrm{~cm}$ of sediment was removed from 6 locations, including tall and short Spartina alterniflora habitat. Natural marsh sediments were combined into 2 replicate pools. In the transplanted marsh, sediment samples were removed from 6 locations in the marsh, similar in elevation to the sediment collection sites in the natural marsh. Surface sediment was also collected from a subtidal portion of the transplanted marsh, along the banks of a tidal creek. Sediments for $\mathrm{C}$ and $\mathrm{N}$ analysis were acid-washed, rinsed, and ground prior to analysis. S analysis was only performed on natural marsh sediment. This sample was treated as above except that no acid wash was performed.

Benthic macroalgae were collected at low tide from the transplanted marsh in April 1993. Specimens of the green alga Ulva lactuca, and the red algae Chaetomorpha linum and a Dasya sp. were removed from the marsh surface and tidal creek. Samples were rinsed with distilled water, dried, ground and stored at $70^{\circ} \mathrm{C}$.

Benthic microalgae were collected from within the Spartina alterniflora zone in July and September 1992 and April 1993 as described by Couch (1989) with slight modifications. A 0.1 to $0.2 \mathrm{~cm}$ layer of ashed, acidwashed $(10 \% \mathrm{HCl})$ beach sand was spread beneath and between 2 layers of $63 \mu \mathrm{m}$ netting. Moisture was maintained with the addition of filtered $(0.2 \mu \mathrm{m})$ seawater. After 12 to $24 \mathrm{~h}$ incubation under laboratory lights (50 to $200 \mu \mathrm{E} \mathrm{m} \mathrm{m}^{-2} \mathrm{~s}^{-1}$ ), the top sand layer was harvested, centrifuged (2000 rpm, ca $1500 \times \mathrm{g}$ ), and the supernatant filtered through an ashed Whatman GF/C filter. Additionally, the top layer of netting was scraped 
with a stainiess steel spatula and this material added to the filtered material. Filters from 6 microalgal separations, obtained in July and September, were pooled into a single sample representing summer 1992. Wet mounts of the sample material were examined with light and phase-contrast microscopy. Sediment, detritus, phytoplankton, and invertebrates were not observed under microscopic examination, although protozoans were observed, but not removed. Pennate diatoms and cyanobacteria dominated the microalgal community. In summer 1992, cyanobacteria included filamentous non-heterocystous forms (Lyngbya aestuarii, Microcoleus chthonoplastes), heterocystous forms (Anabaena spp., Calothrix spp.) and coccoid cyanobacteria. In April 1993, heterocystous cyanobacteria were the most common cyanbacterial type. A blank $C$ value was calculated for the 1992 benthic microalgal samples, based on separate analyses of the sand. Samples collected from April 1993 were not blank-corrected as the sample was large enough to dwarf the small amount of $C$ remaining in the sand ( $R$. Michener pers. comm.). $\mathrm{N}$ and $\mathrm{S}$ were undetectable in the sand.

Epiphytic algae from standing dead Spartina alterniflora were scraped from the stem with forceps. The scraped material included epiphytic microorgansims, sedimentary particles and $S$. alterniflora epidermis. The latter was fibrous and easily removed from the sample. Epiphytic microalgae were not separated from enmeshed sediment particles. Diatoms were rare to absent, and the microalgae were dominated by the cyanobacteria Calothrix spp. and Lyngbya aestuarii. The organic matter content of the epiphytic microalgal film typically ranges from 40 to $60 \%$ (Currin 1994). The sample was ground, acid-washed (except for samples for $\mathrm{S}$ analysis), rinsed in distilled water, and dried at $70^{\circ} \mathrm{C}$.

Faunal samples were collected from both the transplanted and natural marshes. These marshes are adjacent, but separated by a sand berm which limits intermixing of resident populations. After collection, all snail and crab specimens were held in fresh seawater which was changed 4 times over a $24 \mathrm{~h}$ period. All animals were frozen prior to further processing. Periwinkles Littoraria irrorata (Say) were removed from Spartina alterniflora stems and the marsh surface in July 1992 and April 1993 from each marsh, and ca 20 individuals were pooled per sample. In samples for $\mathrm{C}$ and $\mathrm{N}$ analysis, the soft tissue was dissected from the shells, acidified overnight in $1 \mathrm{~N} \mathrm{HCl}$, washed 4 times with distilled water, dried, ground with a mortar and pestle, and stored at $70^{\circ} \mathrm{C}$. Tissue for $\mathrm{S}$ analysis was treated similarly, but without the acid wash. Approximately 20 mud snails Ilyanassa obsoleta were collected from creek banks in each marsh and treated as above. Sand fiddler crabs Uca pugilator (Bosc.) were collected in July from both marshes and dissected into muscle (claw and carapace meat) and gill fractions. Whole crab fractions were also analyzed. These fractions were not acidified, but otherwise treated as above. The ratio of male to female crabs collected was $5: 1$, and the mean carapace length was ca $1.2 \mathrm{~cm}$. Mud fiddlers Uca pugnax (Smith) were collected only from the natural marsh, with a similar male: female ratio and a slightly larger carapace length than $U$. pugilator. The long-nose killifish Fundulus majalis (Walbaum) was seined from a tidal creek in the transplanted marsh, but was absent from natural marsh collections. Conversely, $F$. heteroclitus was dominant in the natural marsh tidal creek, but was rare in the transplanted marsh. For both species, ca 10 individuals were scaled and filleted, and the muscle tissue washed, dried, ground, and stored as above.

Isotopic analysis. The purification of $\mathrm{CO}_{2}$ and $\mathrm{N}_{2}$ gases and determination of stable isotopic ratios with mass spectrometry were performed at the Boston University Stable Isotope Laboratory. Samples were combusted in a Heraeus $\mathrm{C}-\mathrm{N}$ analyzer and cryogenically separated in a Finnigan CT-box prior to analysis with a Finnigan Delta-S isotope ratio mass spectrometer. The sample isotope ratio was compared to a secondary gas standard, whose isotope ratio was calibrated to international standards. All international standards were obtained from the National Bureau of Standards, Gaithersburg, Maryland, USA. Internal instrument precision is $0.014 \%$, and typical sample precision is better than $0.1 \%$ (R. Michener pers. comm.).

$S$ isotopic analyses were performed at the Stable Isotope Laboratory of the Marine Biological Laboratory in Woods Hole, Massachusetts, USA. After combustion, sulfate was precipitated as $\mathrm{BaSO}_{4}$, converted to $\mathrm{SO}_{2}$, and the isotopic ratio determined by mass spectrometry.

Stable isotope ratios are reported in standard $\delta$ notation as follows:

$$
\delta X=\left[\left(R_{\text {sample }} / R_{\text {standard }}\right)-1\right] \times 1000
$$

where $X$ is ${ }^{13} \mathrm{C},{ }^{15} \mathrm{~N}$, or ${ }^{34} \mathrm{~S}$, and $R$ is ${ }^{13} \mathrm{C} /{ }^{12} \mathrm{C},{ }^{15} \mathrm{~N} /{ }^{14} \mathrm{~N}$, or ${ }^{34} \mathrm{~S} / 32 \mathrm{~S}$, respectively. Values are expressed on a per mil (\%o) basis.

\section{RESULTS}

The stable isotopic ratios of primary producers in the natural and transplanted salt marshes are displayed in Table 1 . The $\delta^{13} \mathrm{C}$ values of live, senescent, and standing dead Spartina alterniflora in both marshes varied little (range -12.3 to $-13.1 \%$ ) (Fig. 1a). The $\delta^{15} \mathrm{~N}$ value of live Spartina alterniflora was $1.4 \%$ lighter (more negative) in the transplanted marsh than in the natural 
Table 1. Isotopic composition (\%) of primary producers and sediment in Port Marsh, North Carolina salt marshes. Site codes are TPL: transplanted marsh, NAT: natural marsh, TPLCRK: creek at mouth of transplanted marsh. Unless noted otherwise, all measures are a single analysis of a pooled sample representing 5 to 10 plants, plankton tows, or microalgal collectons. Spartina alterniflora samples are free of epiphytes

\begin{tabular}{|c|c|c|c|c|c|}
\hline Type of sample & Site & $\delta^{13} \mathrm{C}$ & $\delta^{15} \mathrm{~N}$ & $\delta^{34} S$ & $\begin{array}{c}\text { Month } \\
\text { collected }\end{array}$ \\
\hline Live $S$. alterniflora & $\begin{array}{l}\text { TPL } \\
\text { NAT }\end{array}$ & $\begin{array}{l}-12.7 \\
-13.0\end{array}$ & $\begin{array}{l}3.9 \\
5.3\end{array}$ & $\begin{array}{r}3.3 \\
-9.6\end{array}$ & $\begin{array}{l}6 \\
6\end{array}$ \\
\hline $\begin{array}{l}\text { Senescent } S \text {. alterniflora } \\
\text { leaves } \\
\text { stem }\end{array}$ & $\begin{array}{l}\text { TPL } \\
\text { TPL } \\
\text { TPL }\end{array}$ & $\begin{array}{l}-12.9 \\
-12.9\end{array}$ & $\begin{array}{l}2.5 \\
1.6\end{array}$ & $\begin{array}{r}-5.2 \\
1.4 \\
-2.8\end{array}$ & $\begin{array}{r}9 \\
11 \\
11\end{array}$ \\
\hline Standing dead S. alterniflora & $\begin{array}{l}\text { TPL } \\
\text { TPL } \\
\text { TPL } \\
\text { TPL } \\
\text { NAT } \\
\text { NAT } \\
\text { NAT }\end{array}$ & $\begin{array}{c}-13.0(0.2)^{\mathrm{a}} \\
-13.1(0.1)^{\mathrm{a}} \\
-13.0 \\
-12.3 \\
-12.4(0.1)^{\mathrm{a}}\end{array}$ & $\begin{array}{c}1.0(0.5)^{\mathrm{a}} \\
1.5(0.5)^{\mathrm{a}} \\
0.1 \\
2.1 \\
3.8(0.9)^{\mathrm{d}}\end{array}$ & $\begin{array}{c}12.9(1.5)^{\mathrm{d}} \\
8.9 \\
9.2 \\
\\
8.4 \\
8.5\end{array}$ & $\begin{array}{r}4 \\
7 \\
9 \\
11 \\
4 \\
9 \\
11\end{array}$ \\
\hline $\begin{array}{l}\text { Benthic microalgae } \\
\text { Epiphytic microalgae } \\
\text { Benthic microalgae } \\
\text { Benthic microalgae }\end{array}$ & $\begin{array}{l}\text { TPL } \\
\text { TPL } \\
\text { TPL } \\
\text { NAT }\end{array}$ & $\begin{array}{c}-17.4(0.3)^{a} \\
-14.8 \\
-13.0 \\
-17.6\end{array}$ & $\begin{array}{c}-1.0(0.5)^{\mathrm{a}} \\
1.1 \\
-0.1 \\
-1.1\end{array}$ & $\begin{array}{c}-0.1(0.5)^{\mathrm{d}} \\
3.9\end{array}$ & $\begin{array}{c}4 \\
6 \\
7,9 \\
4\end{array}$ \\
\hline $\begin{array}{l}\text { Ulva sp. } \\
\text { Chaetomorpha sp. } \\
\text { Dasya sp. }\end{array}$ & $\begin{array}{l}\text { TPL } \\
\text { TPL } \\
\text { TPL }\end{array}$ & $\begin{array}{l}-15.5 \\
-21.7 \\
-32.8\end{array}$ & $\begin{array}{l}8.1 \\
6.6 \\
8.1\end{array}$ & & $\begin{array}{l}4 \\
4 \\
4\end{array}$ \\
\hline Suspended particulates & TPLCRK & -20.3 & 6.0 & & 7 \\
\hline $\begin{array}{l}\text { Surface sediment } \\
\text { Subtidal sediment } \\
\text { Surface sediment } \\
\text { Surface sediment }\end{array}$ & $\begin{array}{l}\text { TPL } \\
\text { TPL } \\
\text { NAT } \\
\text { NAT }\end{array}$ & $\begin{array}{c}-16.3(1.3)^{\mathrm{b}} \\
-14.0 \\
-18.6(0.3)^{\mathrm{a}}\end{array}$ & $\begin{array}{c}2.4(0.4)^{\mathrm{b}} \\
4.2 \\
2.7(0.8)^{\mathrm{a}}\end{array}$ & -3.9 & $\begin{array}{l}4 \\
4 \\
4 \\
7\end{array}$ \\
\hline
\end{tabular}

marsh. Senescent $S$. alterniflora in the transplanted marsh had an average $\delta^{15} \mathrm{~N}$ value of $2.1 \%$, slightly lighter than that of live $S$. alterniflora. Standing dead $S$. alterniflora collected from the transplanted marsh in July and November 1992 and April 1993 had a mean $\delta^{15} \mathrm{~N}$ of $+0.9 \%$, while standing dead material collected from the natural marsh (April and November only) averaged $+2.9 \%$. Overall, in the transplanted marsh a negative trend was apparent in $\delta^{15} \mathrm{~N}$ values as $S$. alterniflora aboveground tissue decomposed (Fig. 1b). This trend was not as marked in samples from the natural marsh.

The $\delta^{34} \mathrm{~S}$ values of Spartina alterniflora showed differences both between the transplanted and natural marsh, and between live or senescent plants and standing dead material (Table 1, Fig, 1). In June, there was nearly a $13 \%$ difference between the $\delta^{34} \mathrm{~S}$ of natural and transplanted marsh live $S$. alterniflora. Senescent leaves and stems collected in September and November in the transplanted marsh had a $\delta^{34} \mathrm{~S}$ value slightly lighter than live tissue collected in June, and closer to the $\delta^{34} \mathrm{~S}$ value of live S. alterniflora from the natural marsh. The $\delta^{34} \mathrm{~S}$ value of standing dead $S$. alterniflora in both transplanted and natural marshes was $\geq+8.5 \%$ on all sampling dates (Table 1 ). Standing dead $S$. alterniflora in the transplanted marsh had slightly heavier (more positive) $\delta^{34} \mathrm{~S}$ values than natural marsh standing dead $S$. alterniflora, perhaps reflecting the heavier $\delta^{34} \mathrm{~S}$ in live transplanted $S$. alterniflora. The highest $\delta^{34} \mathrm{~S}$ value $(+13.9 \%)$ was recorded for standing dead $S$. alterniflora collected from the transplanted marsh in July.

Benthic microalgae collected in July and September (combined) and epiphytic microalgae collected in June had similar $\mathrm{C}, \mathrm{N}$, and $\mathrm{S}$ isotopic signatures, despite differences in habitat (sediment surface versus standing dead Spartina alterniflora stem) and collection technique (migration through nylon screens for particle removal versus scraped from stem) (Table 1). However, benthic microalgae collected in April from both the natural and transplanted marshes had much lighter $\delta^{13} \mathrm{C}$ values ( -17.6 and $-17.4 \%$, respectively). The $\delta^{15} \mathrm{~N}$ values obtained for Port Marsh benthic and epiphytic microalgae exhibited a range from +1.1 to $-1.1 \%$. The 
STABLE ISOTOPE COMPOSITION Spartina altemiflora
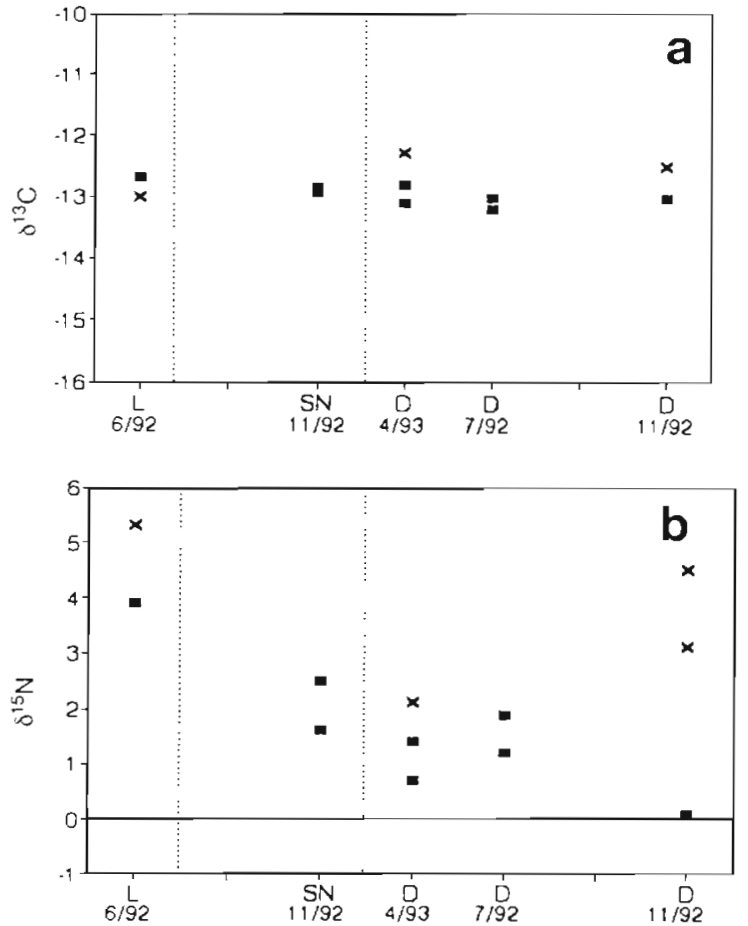

$\delta^{34} \mathrm{~S}$ values obtained for benthic and epiphytic microalgae were +3.9 and $-0.1 \%$, respectively.

The greatest range in $\delta^{13} \mathrm{C}$ values for primary producers was found in the 3 species of benthic macroalgae collected from the transplanted salt marsh (Table 1). The red alga Dasya sp. was the lightest $(-32.8 \%)$, whereas the green algae Chaetomorpha linum was intermediate $(-21.7 \%)$, and Ulva lactuca had the heaviest $(-15.5 \%) \quad \delta^{13} \mathrm{C}$ signature. In contrast to the $\mathrm{C}$ isotopic ratios, the $\delta^{15} \mathrm{~N}$ values for the Port Marsh benthic macroalgae varied little, with a mean value of $+7.6 \%$.

The suspended particulate material collected had $\delta^{13} \mathrm{C}$ and $\delta^{15} \mathrm{~N}$ values of -20.3 and $+6.0 \%$, respectively (Table 1), similar to those reported from other estuarine environments (Thayer et al. 1978, Peterson et al. 1986, Cifuentes et al. 1988, Fogel et al. 1992). Although we were not able to collect enough material to determine the $\delta^{34} \mathrm{~S}$ value, it probably lies near the value of seawater sulfate, $+20 \%$ (Peterson et al. 1986, Nriagu et al. 1991), although a $\delta^{34} \mathrm{~S}$ value of $+11 \%$ was reported by Sullivan \& Moncreiff (1990) for salt marsh zooplankton in Mississippi.

Sediment collected from the transplanted marsh surface in April had an average $\delta^{13} \mathrm{C}$ value of $-16.3 \%$ and an average $\delta^{15} N$ value of $+2.4 \%$ (Table 1 ). Subtidal sediment from a marsh creek had slightly heavier $\mathrm{C}$ and $N$ isotopic values. Surface sediment collected from the

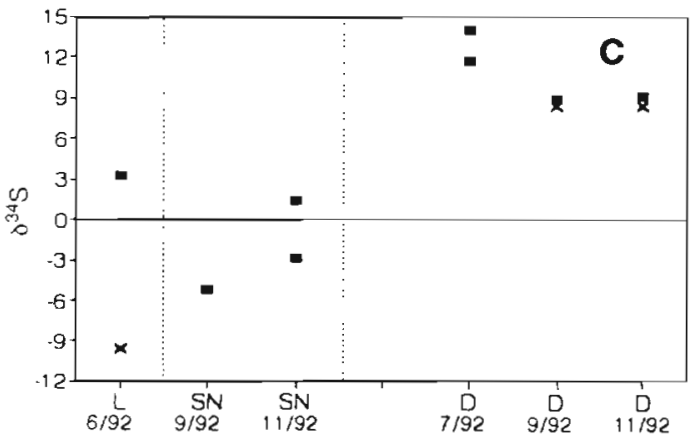

\section{- tPl MARSH $\times$ NAT MARSH}

Fig. 1. (a) Stable C. (b) N, and (c) S isotopic composition (\%) of aboveground Spartina alterniflora collected at various growth stages from either a natural or transplanted marsh. Growth stages are indicated as L: living, green tissue; SN: senescent, yellow tissue; and $\mathrm{D}$ : dead, brown tissue. Month/year of collection given below growth stage. Each point represents a pooled sample of 10 to 20 plants, or the mean of 2 replicate pooled samples (see footnotes in Table 1)

natural marsh had lighter $\delta^{13} \mathrm{C}$ values than transplanted sediments, although the $\delta^{15} \mathrm{~N}$ values were similar. In April, $\mathrm{N}_{2}$-fixing cyanobacteria were present in the surface sediments of both natural and transplanted marshes. The only sedimentary $\delta^{34} \mathrm{~S}$ value we were able to obtain was from sediment collected from the natural marsh surface in July. This value $(-3.9 \%)$ is heavier than the sediment $\delta^{34}$ values from Great Sippiwissett Marsh in Massachusetts ( $-11 \%$; Peterson et al. 1986) and from Graveline Marsh in Mississippi $(-11.2 \%$; Sullivan \& Moncreiff 1988b).

We found small differences between the $\delta^{13} \mathrm{C}$ and $\delta^{34} \mathrm{~S}$ values of Ilyanassa obsoleta specimens collected in the natural and transplanted marshes in July (Table 2). Mud snails collected in the spring from the transplanted marsh had heavier $\delta^{13} \mathrm{C}$ values than snails collected in the summer (Table 2). The $3 \delta^{15} \mathrm{~N}$ values clustered around $+7 \%$.

Littoraria irrorata samples showed a small but consistent trend of lighter $\delta^{13} \mathrm{C}$ and $\delta^{15} \mathrm{~N}$ values in samples from the transplanted marsh than in the natural marsh (Table 2). In contrast, the $\delta^{34} S$ value determined for periwinkles in the transplanted marsh $(+14.9 \%)$ was heavier than that in the natural marsh $(+12.3 \%)$.

Uca pugilator was found in both the natural and transplanted marshes, while $U$. pugnax was restricted to the natural marsh. In July, the $\delta^{13} \mathrm{C}$ of muscle and gill tissue from $U$. pugilator collected in the transplanted 
Table 2. Isotopic composition (\%) of consumer organisms in Port Marsh, North Carolina. Site codes are TPL: transplanted marsh and NAT: natural marsh. All measures are a single analysis of a pooled sample representing 10 to 20 animals

\begin{tabular}{|lllllc|}
\hline Type of sample & Site & $\delta^{13} \mathrm{C}$ & $\delta^{15} \mathrm{~N}$ & $\delta^{34} \mathrm{~S}$ & $\begin{array}{c}\text { Month } \\
\text { collected }\end{array}$ \\
\hline Ilyanassa obsoleta & TPL & -13.8 & 6.9 & & 4 \\
& TPL & -15.2 & 7.5 & 5.9 & 7 \\
& NAT & -13.2 & 6.8 & 7.2 & 7 \\
Littoraria irrorata & TPL & -16.3 & 3.6 & & 4 \\
& TPL & -15.1 & 2.2 & 14.9 & 7 \\
& NAT & -16.6 & 3.7 & & 4 \\
NAT & -16.1 & 3.1 & 12.3 & 7 \\
Uca pugilator, muscle & TPL & -13.1 & 3.8 & 8.9 & 7 \\
gill & TPL & -13.8 & 3.3 & & 7 \\
whole & TPL & -12.6 & 2.8 & & 7 \\
gill & NAT & -16.4 & 4.3 & 8.3 & 7 \\
NAT & -17.4 & 3.6 & & 7 \\
U. pugnax, muscle & NAT & -17.5 & 4.0 & 7.5 & 7 \\
Fundulus majalis & TPL & -14.1 & 9.2 & 4.7 & 7 \\
F. heteroclitus & NAT & -15.9 & 9.3 & 5.2 & 7 \\
\hline
\end{tabular}

marsh was ca $3 \%$ heavier than crabs collected from the natural marsh (Table 2). The $\delta^{13} \mathrm{C}$ of transplanted marsh whole crab tissue was slightly heavier than soft tissue, as a result of carbonates bound in the chitinous shell (Haines \& Montague 1979). The $\delta^{13} \mathrm{C}$ value of $U$. pugnax muscle tissue was $1 \%$ lighter than that of $U$. pugilator in the natural marsh. The $\delta^{15} \mathrm{~N}$ values of fiddler crabs from the transplanted and natural salt marsh were similar, exhibiting a range of +2.8 to $+4.3 \%$ (Table 2 ). The lighter $\delta^{15} \mathrm{~N}$ of whole crab tissue is due to the presence of chitin in the crab shell (DeNiro \& Epstein 1981). $\delta^{34} \mathrm{~S}$ was heavier in $U$. pugilator muscle (mean $8.6 \%$ ) than in $U$. pugnax tissue $(+7.5 \%)$.

The $\delta^{15} \mathrm{~N}$ and $\delta^{34} \mathrm{~S}$ values of Fundulus majalis from the transplanted marsh were similar to $F$. heteroclitus values, while there was a $1.8 \%$ difference in the $\delta^{13} \mathrm{C}$ values of the 2 species (Table 2)

\section{DISCUSSION}

\section{Effects of aerial decomposition on stable isotopic values of Spartina alterniflora}

Standing dead Spartina alterniflora had $\delta^{13} \mathrm{C}$ values similar to live $S$. alterniflora, and it thus appears that aerial decomposition does not significantly alter the $\delta^{13} \mathrm{C}$ value of $S$. alterniflora. Although an increase in relative lignin content has been well documented in litterbag incubations (Benner et al. 1987), less is known of the changes in lignin composition via aerial decomposition. Hodson et al. (1984) reported a Klason lignin content of
18 to $21 \%$ for standing dead S. alterniflora, in contrast to 14 to $15 \%$ in mature, live plant tissue. However, Klason 'lignin' can include fungal cell wall material (Newell 1993). Haddad et al. (1992) compared lignin degradation in standing dead versus litterbag detritus by analyzing lignin oxidation products, and concluded that most of the calculated lignin loss occurred during aerial decomposition. We document standing dead $\delta^{13} \mathrm{C}$ values near the value of live tissue (Tables 1 \& 3 ), indicating that lignin is degraded at the same relative rate as other compounds during aerial decomposition. The average $\delta^{13} \mathrm{C}$ value for sedimentary and/or litterbag $S$. alterniflora detritus reported in the literature is $-15.0 \%$ (Table 3 ), and apparently occurs as a result of lower rates of lignin degradation under those circumstances (Benner et al. 1987).

There was also a change in $\delta^{15} \mathrm{~N}$ values from live to senescent and standing dead Spartina alterniflora, particularly evident in the transplanted marsh samples, where there was nearly a $4 \%$ shift (Fig. 1b). Total $N$ content of live plants in the natural and transplanted marsh was similar, and averaged about $1.0 \%$ (C. Currin \& S. Broome unpubl.). The decrease in the $\delta^{15} \mathrm{~N}$ value of standing dead $S$. alterniflora could be a result of selective remineralization of isotopically heavier $\mathrm{N}$. In experimental rice fields, selective decomposition of heavier isotopic species was observed, with a resultant decrease in soil organic $\delta^{15} \mathrm{~N}$ values (Wada \& Hattori 1991). Given the low $N$ content of $S$. alterniflora $(1.0 \%)$, microbial decomposition of this material would also require uptake of dissolved ammonium. Bacteria preferentially utilize ${ }^{14} \mathrm{NH}_{4}$ (Wada \& Hattori 1991, Hoch et al. 1992), and so the process of microbial degradation should result in an overall decrease in the $\delta^{15} \mathrm{~N}$ value. However, the microbial community in standing dead tissue is dominated by fungi, rather than bacteria (Newell et al. 1989), and little is known about the possible nitrogen isotope fractionation of fungal dissolved inorganic nitrogen (DIN) uptake. Another mechanism leading to isotopically lighter $\mathrm{N}$ is $\mathrm{N}_{2}$ fixation. The lower $20 \mathrm{~cm}$ of standing dead $S$. alterniflora was frequently colonized by an epiphytic community dominated by $\mathrm{N}_{2}$-fixing cyanobacteria (Currin 1994). $\mathrm{N}_{2}$-fixation rates on standing dead stems in the transplanted marsh were significantly greater than rates in the natural marsh (Currin 1994), consonant with the greater decrease in $\delta^{15} \mathrm{~N}$ values on $S$. alterniflora stems in the transplanted marsh. Standing dead $S$, alterniflora in Georgia also supported a $\mathrm{N}_{2}$ fixing community, although heterotrophic bacteria were hypothesized to have been the dominant $\mathrm{N}_{2}$ fixers there (Newell et al. 1992). In both cases, rates of $\mathrm{N}_{2}$ fixation as estimated by acety- 
Table 3. A summary of published stable isotope values for living, standing dead and detrital Spartina alterniflora, benthic microalgae and macroalgae, phytoplankton, and selected salt marsh macrofauna. Sample descriptions are as originally reported in the literature. U.S. states are given without a country name. S. alterniflora material is aboveground (stems and leaves) unless noted otherwise. sed.: sedimentary; susp.. suspended; rhiz.: rhizome; surf.: surface. Detrital S. alterniflora was collected from litterbag or laboratory studies if decomposition time is indicated in parentheses; otherwise detritus was collected in situ. Suspended particulates are from estuarine environments; mesh size is shown in parentheses when known. Macroalgal material is from both coastal marine and estuarine environments. In many cases, results were grouped according to family. The number of species is given in parentheses. Microalgal material is from estuarine environments. All fauna samples were collected from salt marshes

\begin{tabular}{|c|c|c|c|c|c|}
\hline Organism & Location & $\delta^{13} \mathrm{C}$ & $\delta^{15} \mathrm{~N}$ & $\delta^{34} \mathrm{~S}$ & Source \\
\hline \multicolumn{6}{|l|}{ Spartina alterniflora } \\
\hline \multirow[t]{18}{*}{ Live S. alterniflora } & Georgia & -12.6 & 6.6 & & Fogel et al. (1989) \\
\hline & Georgia & -13.1 & & & Haines (1976) \\
\hline & Georgia & & 6.2 & & Mariotti et al. (1983) \\
\hline & Georgia & -12.9 & 6.0 & 0.9 & Peterson \& Howarth (1987) \\
\hline & Louisiana & -12.5 & 15.3 & 5.6 & Deegan et al. (1990) \\
\hline & Massachusetts & -13.2 & 3.8 & -2.0 & Peterson et al. $(1985,1986)$ \\
\hline & Mississippi & -12.4 & & & Hackney \& Haines (1980) \\
\hline & Mississippi & -13.2 & 5.2 & 1.4 & Sullivan \& Moncreiff (1990) \\
\hline & North Carolina transplant & -12.0 & 1.6 & & Craft et al. (1988) \\
\hline & North Carolina transplant & -12.7 & 3.9 & 3.3 & This study \\
\hline & North Carolina & & & 0.0 & Carlson \& Forrest (1982) \\
\hline & North Carolina & -13.0 & 5.3 & -9.6 & This study \\
\hline & North Carolina & -13.6 & & & Thayer et al. (1978) \\
\hline & Nova Scotia, Canada & -13.1 & & & Schwinghamer et al. (1983) \\
\hline & Nova Scotia, Canada & -12.9 & & & Stephenson et al. (1986) \\
\hline & South Carolina & -14.3 & 4.3 & & Couch (1989) \\
\hline & South Carolina & -13.6 & & & Ember et al. (1987) \\
\hline & lexas & & & 4.0 & Fry et al. (1982b) \\
\hline Group means & & -13.0 & 5.8 & 0.5 & \\
\hline SE & & 0.5 & 3.5 & 4.4 & \\
\hline \multirow[t]{2}{*}{ Senescent S. alterniflora } & South Carolina & -13.7 & & & Ember et al. (1987) \\
\hline & North Carolina transplant & -12.9 & & -3.3 & This study \\
\hline \multirow[t]{5}{*}{ Standing dead $S$. alterniflora } & Georgia & -12.3 & & & Haines (1976) \\
\hline & North Carolina transplant & -13.1 & 1.6 & 10.4 & This study \\
\hline & North Carolina & -12.5 & 2.9 & 8.5 & This study \\
\hline & Nova Scotia, Canada & -13.2 & & & Schwinghamer et al. (1983) \\
\hline & South Carolina & -12.7 & 2.9 & & Couch (1989) \\
\hline \multicolumn{2}{|l|}{ Group means } & -12.8 & 2.5 & 9.5 & \\
\hline \multicolumn{2}{|l|}{$\mathrm{SE}$} & 0.3 & 0.6 & 1.0 & \\
\hline \multirow{11}{*}{$\begin{aligned} \text { Detrital S. alterniflora, sed. } \\
\text { susp. } \\
\text { sed. } \\
\text { sed. } \\
(125 \mathrm{~d}) \\
(3 \mathrm{mo}) \\
(7.2 \mathrm{mo}) \\
(15 \mathrm{mo}, \text { surf }) \\
(15 \mathrm{mo}, \text { buried }) \\
(16.5 \mathrm{mo}) \\
\text { rhiz. }(18 \mathrm{mo})\end{aligned}$} & Georgia & -16.0 & & & Fogel et al. (1989) \\
\hline & Nova Scotia, Canada & -17.7 & & & Schwinghamer et al. (1983) \\
\hline & Nova Scotia, Canada & -18.8 & & & Schwinghamer et al. (1983) \\
\hline & South Carolina & -16.3 & 2.8 & & Couch (1989) \\
\hline & Nova Scotia, Canada & -14.4 & & & Stephenson et al. (1986) \\
\hline & Georgia & -12.9 & 12.5 & & Fogel et al. (1989) \\
\hline & North Carolina & -12.7 & & & Haddad et al. (1992) \\
\hline & South Carolina & -13.8 & & & Ember et al. (1987) \\
\hline & South Carolina & -15.4 & & & Ember et al. (1987) \\
\hline & North Carolina & -13.2 & & & Haddad et al. (1992) \\
\hline & Georgia & -1.4 .1 & & & Benner et al. (1987) \\
\hline \multirow{2}{*}{\multicolumn{2}{|c|}{$\begin{array}{l}\text { Group means } \\
\text { SE }\end{array}$}} & -15.0 & 7.7 & & \\
\hline & & 1.9 & 4.9 & & \\
\hline \multicolumn{6}{|l|}{ Phytoplankton } \\
\hline \multirow{2}{*}{$\begin{array}{l}\text { Blue-green algal blooms } \\
\text { Trichodesmium bloom }\end{array}$} & Florida, Gulf & -14.8 & & & Fry \& Sherr (1984) \\
\hline & Texas? & -14.6 & & & Calder \& Parker (1973) \\
\hline Particulates $(1 \mu \mathrm{m})$ & Delaware & -21.1 & 9.3 & & Cifuentes et al. (1988) \\
\hline Particulates $(1 \mu \mathrm{m})$ & Delaware & -27.2 & & & Fogel et al. (1992) \\
\hline \multirow{2}{*}{$\begin{array}{l}\text { Particulates }(1 \mu \mathrm{m}) \\
\text { Particulates }(20 \mu \mathrm{m})\end{array}$} & Delaware & -20.6 & & & Fogel et al. (1992) \\
\hline & Georgia & -19.2 & 6.6 & & Fogel et al. (1989) \\
\hline \multirow{2}{*}{$\begin{array}{l}\text { Plankton }(153 \mu \mathrm{m}) \\
\text { Particulates }(20 \mu \mathrm{m})\end{array}$} & Massachusetts & -21.0 & 8.6 & 18.6 & Peterson et al. $(1985,1986)$ \\
\hline & North Carolina & -20.3 & 6.0 & & This study \\
\hline
\end{tabular}


Table 3 (continued)

\begin{tabular}{|c|c|c|c|c|c|}
\hline Organism & Location & $\delta^{13} \mathrm{C}$ & $\delta^{15} \mathrm{~N}$ & $\delta^{34} S$ & Source \\
\hline Particulates (176 $\mu \mathrm{m})$ & North Carolina & -20.0 & & & Thayer et al. (1978) \\
\hline Phytoplankton & Nova Scotia, Canada & -19.2 & & & Schwinghamer et al. (1983) \\
\hline Group means & & -21.1 & 7.6 & 18.6 & \\
\hline $\mathrm{SE}$ & & 2.4 & 1.4 & & \\
\hline \multicolumn{6}{|l|}{ Benthic macroalgae } \\
\hline Benthic macroalgae & Australia & -13.6 & & & Fry et al. (1983) \\
\hline Benthic Chlorophyta (13 sp.) & Caribbean & -17.0 & & & Fry et al. $(1982 \mathrm{a}\}$ \\
\hline Benthic Phaeophyta (6sp.) & Caribbean & -12.2 & & & Fry et al. (1982a) \\
\hline Benthic Rhodophyta (10 sp.) & Caribbean & -17.9 & & & Fry et al. (1982a) \\
\hline Fucus virsoides & Gulf of Trieste & -15.6 & & & Faganeli et al. (1986) \\
\hline Ulva rigida & Gulf of Trieste & -17.6 & & & Faganeli et al. (1986) \\
\hline Codium sp. & Massachusetts & & & 19.9 & Peterson et al. (1986) \\
\hline Ascophyllum sp. & Massachusetts & & & 15.1 & Peterson et al. (1986) \\
\hline Filamentous algae & Mississippi & -20.6 & 7.7 & 13.1 & Sullivan \& Moncreiff (1990) \\
\hline Benthic macroalgae & North Carolina & -16.9 & & & Raven \& Osmond (1992) \\
\hline Ulva sp. & North Carolina & -15.5 & 8.1 & & This study \\
\hline Chaetomorphasp. & North Carolina & -21.7 & 6.6 & & This study \\
\hline Dasya sp. & North Carolina & -32.8 & 6.6 & & This study \\
\hline Ulva sp. & Nova Scotia, Canada & -4.9 & & & Schwinghamer et al. (1983) \\
\hline Enteromorpha sp. & Nova Scotia, Canada & -9.6 & & & Schwinghamer et al. (1983) \\
\hline Marine macroalgae & Multiple locations & & 6.0 & & Wada \& Hattori (1991) \\
\hline Benthic Phaeophyta (15 sp.) & Scotland, UK & -16.9 & & & Maberly et al (1992) \\
\hline Benthic Chlorophyta (8sp.) & Scotland, UK & -14.3 & & & Maberly et al. (1992) \\
\hline Benthic Rhodophyta (16 sp.) & Scotland, UK & -18.6 & & & Maberly et al. (1992) \\
\hline Benthic macroalgae & Texas & & & 17.3 & Fry et al. $(1982 b)$ \\
\hline Group means & & -16.6 & 7.0 & 16.4 & \\
\hline $\mathrm{SE}$ & & 5.8 & 0.8 & 2.5 & \\
\hline \multicolumn{6}{|l|}{ Benthic microalgae } \\
\hline Cyanobacterial mat & Arabia & -8.5 & & & Calder \& Parker (1973) \\
\hline Filamentous blue-green algae & Massachusetts & & & 18.2 & Peterson et al. (1986) \\
\hline Blue-green algal mat & Massachusetts & & & 13.1 & Peterson et al. (1986) \\
\hline Diatoms (Gyrosigma sp.) & Georgia & -17.9 & & & Haines (1976) \\
\hline Creekbank diatoms & Georgia & -16.2 & & & Haines (1976) \\
\hline Diatoms (Euglena sp.) & Georgia & -17.0 & & & Haines (1976 \\
\hline Benthic algae & Georgia & & 3.9 & & Mariotti et al. (1983) \\
\hline Creekbank algae & Georgia & -16.7 & 3.5 & & Peterson \& Howarth (1987) \\
\hline Diatom (Amphipleura sp.) & Maine & -12.4 & & & Incze et al. (1982) \\
\hline Edaphic algae & Mississippi & -20.6 & 6.1 & 14.3 & Sullivan \& Moncreiff (1990) \\
\hline Floating algae & North Carolina transplant & -16.8 & 0.7 & & Craft et al. (1988) \\
\hline Benthic algae & North Carolina transplant & -16.7 & 0.8 & & Craft et al. (1988) \\
\hline Epiphytic microalgae & North Carolina transplant & -14.8 & 1.1 & -0.1 & This study \\
\hline Benthic microalgae & North Carolina & -17.4 & -1.0 & & This study \\
\hline Benthic microalgae & North Carolina & -13.0 & -0.1 & 3.9 & This study \\
\hline Diatom (Gyrosigma) & Nova Scotia, Canada & -13.6 & & & Schwinghamer et al. (1983) \\
\hline Diatom (Gyrosigma) & Nova Scotia, Canada & -18.1 & & & Schwinghamer et al. (1983) \\
\hline Benthic microalgae & South Carolina & -12.7 & 3.8 & & Couch (1989) \\
\hline Cyanobacteria & St. Croix, Virgin Islands & -9.4 & & & Fry et al. (1982a) \\
\hline Cyanobacterial mat & Texas & -14.9 & & & Calder \& Parker (1973) \\
\hline Cyanobacteria mat & Texas & -11.5 & 1.6 & & Pulich \& Scalan (1987) \\
\hline Diatom-green algae & Texas & & 4.3 & & Pulich \& Scalan (1987) \\
\hline Group means & & -14.9 & 2.2 & 9.9 & \\
\hline SE & & 3.1 & 2.1 & 6.8 & \\
\hline \multicolumn{6}{|l|}{ Meiofauna } \\
\hline Harpacticoid copepods & Nova Scotia, Canada & -14.1 & & & Schwinghamer et al. (1983) \\
\hline Harpacticoid copepods & South Carolina & -14.4 & 5.8 & & Couch (1989) \\
\hline Nematodes, $<125 \mu \mathrm{m}$ & Nova Scotia, Canada & -14.2 & & & Schwinghamer et al. (1983) \\
\hline Nematodes, $>125 \mu \mathrm{m}$ & Nova Scotia, Canada & -13.3 & & & Schwinghamer et al. (1983) \\
\hline Nematodes & South Carolina & -14.9 & 5.3 & & Couch (1989) \\
\hline Group means & & -14.2 & 5.6 & & \\
\hline $\mathrm{SE}$ & & 0.5 & 0.3 & & \\
\hline
\end{tabular}


Table 3 (continued)

\begin{tabular}{|c|c|c|c|c|c|}
\hline Organism & Location & $\delta^{13} \mathrm{C}$ & $\delta^{15} \mathrm{~N}$ & $\delta^{34} \mathrm{~S}$ & Source \\
\hline $\begin{array}{l}\text { Macrofauna } \\
\text { Uca pugilator }\end{array}$ & $\begin{array}{l}\text { Georgia } \\
\text { Georgia } \\
\text { North Carolina transplant } \\
\text { North Carolina } \\
\text { North Carolina }\end{array}$ & $\begin{array}{l}-16.3 \\
-17.8 \\
-13.1 \\
-16.6 \\
-16.4\end{array}$ & $\begin{array}{l}4.0 \\
3.8 \\
4.3\end{array}$ & $\begin{array}{r}13.3 \\
8.9 \\
8.3\end{array}$ & $\begin{array}{l}\text { Haines }(1976) \\
\text { Peterson \& Howarth (1987) } \\
\text { This study } \\
\text { Kneib et al. (1980) } \\
\text { This study }\end{array}$ \\
\hline $\begin{array}{l}\text { Group means } \\
\text { SE }\end{array}$ & & $\begin{array}{r}-16.0 \\
1.6\end{array}$ & $\begin{array}{l}4.1 \\
0.3\end{array}$ & $\begin{array}{l}8.6 \\
0.3\end{array}$ & \\
\hline Uca pugnax & $\begin{array}{l}\text { Georgia } \\
\text { Georgia } \\
\text { Georgia } \\
\text { Massachusetts } \\
\text { Mississippi } \\
\text { North Carolina } \\
\text { North Carolina }\end{array}$ & $\begin{array}{l}-15.1 \\
-16.8 \\
-16.8 \\
-16.2 \\
-15.0 \\
-16.4 \\
-17.5\end{array}$ & $\begin{array}{l}5.0 \\
4.3 \\
7.2 \\
4.0\end{array}$ & $\begin{array}{r}13.0 \\
8.6 \\
14.9 \\
7.5\end{array}$ & $\begin{array}{l}\text { Haines \& Montague (1979) } \\
\text { Haines (1976) } \\
\text { Peterson \& Howarth (1987) } \\
\text { Peterson \& Howarth (1987) } \\
\text { Sullivan \& Moncreiff (1990) } \\
\text { Kneib et al. (1980) } \\
\text { This study }\end{array}$ \\
\hline $\begin{array}{l}\text { Group means } \\
\text { SE }\end{array}$ & & $\begin{array}{r}-16.3 \\
0.9\end{array}$ & $\begin{array}{l}5.1 \\
1.3\end{array}$ & $\begin{array}{r}11.0 \\
3.1\end{array}$ & \\
\hline Fundulus heteroclitus & $\begin{array}{l}\text { Georgia } \\
\text { Massachusetts } \\
\text { Massachusetts } \\
\text { North Carolina } \\
\text { North Carolina }\end{array}$ & $\begin{array}{l}-15.6 \\
-12.0 \\
-15.0 \\
-15.9\end{array}$ & $\begin{array}{r}9.9 \\
10.6\end{array}$ & $\begin{array}{l}4.8 \\
1.0 \\
5.2\end{array}$ & $\begin{array}{l}\text { Peterson \& Howarth (1987) } \\
\text { Peterson \& Howarth (1987) } \\
\text { Peterson et al. (1986) } \\
\text { Kneib et al. (1980) } \\
\text { This study }\end{array}$ \\
\hline $\begin{array}{l}\text { Group means } \\
\text { SE }\end{array}$ & & $\begin{array}{r}-14.6 \\
1.5\end{array}$ & $\begin{array}{l}9.9 \\
0.5\end{array}$ & $\begin{array}{l}3.7 \\
1.9\end{array}$ & \\
\hline Fundulus majalis & $\begin{array}{l}\text { Mississippi } \\
\text { North Carolina transplant }\end{array}$ & $\begin{array}{l}-18.6 \\
-14.1\end{array}$ & $\begin{array}{l}9.6 \\
9.2\end{array}$ & $\begin{array}{l}7.8 \\
4.7\end{array}$ & $\begin{array}{l}\text { Sullivan \& Moncreiff (1990) } \\
\text { This study }\end{array}$ \\
\hline $\begin{array}{l}\text { Group means } \\
\text { SE }\end{array}$ & & $\begin{array}{r}-16.4 \\
2.3\end{array}$ & $\begin{array}{l}9.4 \\
0.2\end{array}$ & $\begin{array}{l}6.3 \\
1.6\end{array}$ & \\
\hline Ilyanassa obsoleta & $\begin{array}{l}\text { Georgia } \\
\text { Georgia } \\
\text { Massachusetts } \\
\text { Massachusetts } \\
\text { Nova Scotia, Canada } \\
\text { North Carolina } \\
\text { North Carolina transplant }\end{array}$ & $\begin{array}{l}-17.8 \\
-15.9 \\
-11.0 \\
-10.7 \\
-13.2 \\
-14.5\end{array}$ & $\begin{array}{l}7.0 \\
4.6\end{array}$ & $\begin{array}{l}2.0 \\
7.2 \\
5.9\end{array}$ & $\begin{array}{l}\text { Peterson \& Howarth (1987) } \\
\text { Haines (1976) } \\
\text { Peterson \& Howarth (1987) } \\
\text { Peterson et al. (1986) } \\
\text { Schwinghamer et al. (1983) } \\
\text { This study } \\
\text { This study }\end{array}$ \\
\hline $\begin{array}{l}\text { Group means } \\
\text { SE }\end{array}$ & & $\begin{array}{r}-13.9 \\
2.5\end{array}$ & $\begin{array}{l}6.4 \\
1.0\end{array}$ & $\begin{array}{l}6.0 \\
2.6\end{array}$ & \\
\hline Littoraria irrorata & $\begin{array}{l}\text { Georgia } \\
\text { Georgia } \\
\text { Georgia } \\
\text { Mississippi } \\
\text { North Carolina transplant } \\
\text { North Carolina } \\
\text { Nova Scotia, Canada }\end{array}$ & $\begin{array}{l}-11.9 \\
-14.7 \\
-16.1 \\
-21.6 \\
-15.7 \\
-16.3 \\
-12.6\end{array}$ & $\begin{array}{l}7.1 \\
\\
2.2 \\
3.4\end{array}$ & $\begin{array}{l}10.7 \\
14.3 \\
14.9 \\
12.3\end{array}$ & $\begin{array}{l}\text { Haines \& Montague (1979) } \\
\text { Haines (1976) } \\
\text { Peterson \& Howarth (1987) } \\
\text { Sullivan \& Moncreiff (1990) } \\
\text { This study } \\
\text { This study } \\
\text { Schwinghamer et al. (1983) }\end{array}$ \\
\hline $\begin{array}{l}\text { Group means } \\
\text { SE }\end{array}$ & & $\begin{array}{r}-15.6 \\
2.9\end{array}$ & $\begin{array}{l}4.2 \\
2.1\end{array}$ & $\begin{array}{r}130 \\
1.7\end{array}$ & \\
\hline
\end{tabular}

lene reduction (nmol $\mathrm{C}_{2} \mathrm{H}_{4} \mathrm{~g}^{-1}$ ash-free dry wt $\mathrm{h}^{-1}$ ) were among the highest rates reported for natural assemblages (Newell et al. 1992, Currin 1994). High rates of $\mathrm{N}_{2}$-fixation are reflected in the $\delta^{15} \mathrm{~N}$ value of $+1.1 \%$ for the epiphytic microalgal community (Table 1). However, the epiphytic microbial film was carefully excluded from standing dead $S$. alterniflora tissue prepared for isotopic analysis. Incorporation of isotopically light fixed $\mathrm{N}$ into the total $\mathrm{N}$ of standing dead $S$. alterniflora would require transfer of fixed $N$ from epiphytic microorganisms to endophytic microorganisms, presumably fungi. Fungal biomass has been 
calculated to represent most of the $\mathrm{N}$ remaining in standing dead shoots (Newell et al. 1989, Newell 1993).

The hypothesis that microbial activity is responsible for the observed shift in the $\delta^{15} \mathrm{~N}$ signature of decomposing Spartina alterniflora is supported by evidence from an investigation of $\mathrm{N}$ incorporation into standing dead $S$. alterniflora in Great Sippewisset Marsh (White \& Howes 1994). That study revealed that 50 to $65 \%$ of the total $\mathrm{N}$ pool in detrital $S$. alterniflora is derived from external sources. Further, the incorporation of the external $\mathrm{N}$ into the detritus was greater in the spring and summer months, which is also the time of highest $\mathrm{N}_{2}$-fixation rates associated with standing dead $S$. alterniflora (Newell et al. 1992, Currin 1994), and presumably the time of highest microbial activity as well If the external $\mathrm{N}$ source was fixed $\mathrm{N}$, or ${ }^{15} \mathrm{~N}$-depleted $\mathrm{NH}_{4}$, then one would expect a decrease in the $\delta^{15} \mathrm{~N}$ signature from live to detrital S. alterniflora.

The observation of a large difference in $\delta^{34} \mathrm{~S}$ values for live Spartina alterniflora from the natural and transplanted marshes is consistent with previous reports of $S$. alterniflora uptake of porewater sulfide. The process of sulfate reduction in salt marsh sediments yields isotopically light porewater sulfide, and the uptake of sulfide by $S$. alterniflora has been demonstrated to yield plant tissue depleted in $\delta^{34} \mathrm{~S}$ (Carlson \& Forrest 1982). Redox potential in the natural marsh was more negative than in the transplanted marsh $\left(E_{h}=-150\right.$ versus $50 \mathrm{mV}$ at $5 \mathrm{~cm}$ depth), and natural marsh porewater had higher sulfide concentrations (5 to $10 \mathrm{ppm}$ versus 0 to $5 \mathrm{ppm}$; L. Hartley \& S. Broome pers. comm.) The more negative $\delta^{34} \mathrm{~S}$ value of natural marsh $S$. alterniflora may therefore reflect increased sulfide uptake and incorporation into plant tissue. Seasonal changes in plant $\delta^{34} \mathrm{~S}$ values could also result from variable rates of sulfide uptake, as marsh porewater sulfide concentrations may increase during summer months due to high rates of sulfate reduction (Howarth \& Giblin 1983). Increased porewater sulfide concentrations may explain the lighter $\delta^{34} \mathrm{~S}$ values of senescent $S$. alterniflora collected in September, relative to plants collected in June from the transplanted marsh (Table 1). A similar seasonal shift was reported for short $S$. alterniflora in Great Sippiwisset Marsh, and differences in the $\delta^{34} \mathrm{~S}$ values between tall and short $S$. alterniflora were also attributed to differences in porewater sulfide concentrations (Peterson et al. 1986)

Standing dead stems collected in the natural and transplanted marsh consistently had heavier $\delta^{34} \mathrm{~S}$ values (range 8.4 to $12.9 \%$ ) than any previously reported for living Spartina alterniflora tissue (Table 3). The relatively heavy $\delta^{34} \mathrm{~S}$ of standing dead $S$. alterniflora, however, cannot be attributed to changes in porewater sulfide concentration or its isotopic composition.
Rather, the standing dead $\delta^{34} \mathrm{~S}$ values represent a shift in isotopic composition within the plant tissue, as senescent tissue collected in November had $\delta^{34} \mathrm{~S}$ values near $0 \%$, and plant uptake of porewater does not occur after senescence.

We consider here several, nonexclusive, mechanisms for the observed shift in the $\delta^{34} \mathrm{~S}$ of standing dead Spartina alterniflora. One possibility is that as the plant decomposes, organic compounds that have a lighter $\delta^{34} \mathrm{~S}$ value are selectively decomposed or lost, resulting in isotopically heavier tissue. However, there is no evidence that the primary forms of organic $S$ in plants (amino acids and sulfolipids) have different $\delta^{34} \mathrm{~S}$ values (Krouse et al. 1991, Trust \& Fry 1992). There is some evidence that the soluble organic, insoluble organic, and inorganic S fractions in plants demonstrate isotopic fractionation, with mineral $S$ being enriched in ${ }^{34} \mathrm{~S}$ (Nriagu et al. 1991). If aerial decomposition of $S$. alterniflora alterniflora resulted in a preferential loss of soluble organic $S$ over inorganic $S$, then a slight enrichment in ${ }^{34} \mathrm{~S}$ may occur. However the difference between tissue sulfate and organic $S$ is only 2 to $3 \%$ (Carlson \& Forrest 1982, Nriagu et al. 1991), and thus is not enough to account for the observed shift. It should also be noted that $S$. alterniflora releases dimethyl sulfide (DMS) and that emissions may increase during leaf senescence (Dacey et al. 1987). In cucumber plants, DMS emissions were depleted in ${ }^{34} \mathrm{~S}$ by $15 \%$ (Winner et al. 1981). Although the concentration of dimethylsulphoniopropinate (DMSP), a precursor of DMS, may represent a substantial portion of the organic $S$ in $S$. alterniflora tissues, the daily turnover rate of DMSP to DMS has been estimated at less than 1\% (Dacey et al. 1987). At present, the degree to which the metabolism of DMSP contributes to the observed changes in standing dead $S$. alterniflora $\delta^{34} \mathrm{~S}$ in unknown.

Another hypothesis is that the standing dead tissue becomes enriched in ${ }^{34} \mathrm{~S}$ via microbial production. Newell et al. (1989) estimated that fungal biomass formed $>90 \%$ of the microbial standing crop and that $C$ flow to fungal biomass was 4 to 5 times that to bacterial biomass. The average $\mathrm{S}$ content of a terrestrial fungus is $0.3 \%$ (Saggar et al. 1981). Fungi can obtain S from seawater sulfate during periods of inundation, via assimilatory sulfate reduction (Griffin 1981). Seawater sulfate has a $\delta^{34} \mathrm{~S}$ value of $+20 \%$. If we assume that living fungal biomass represents 10 to $20 \%$ of the organic content of standing dead Spartina alterniflora (Newell 1993) and is $0.3 \% \mathrm{~S}$ on an AFDW basis, and that fungi obtain all their $\mathrm{S}$ from seawater sulfate, then $1 \mathrm{~g}$ of standing dead tissue would contain 0.3 to $0.6 \mathrm{mg}$ of $+20 \% \mathrm{~S}$. If this were added to $3 \mathrm{mg}$ of plant $\mathrm{S}$ (standing dead tissue = $0.3 \% \mathrm{~S}, \mathrm{~S}$. Broome pers. comm.) with a $\delta^{34} \mathrm{~S}$ of $0 \%$, there would be a shift in the total $\delta^{34} \mathrm{~S}$ of $+2.6 \%$. In order for 
fungal metabolism to account for the significant shift (ca $+10 \%$ ) observed, fungal $\mathrm{S}$ must constitute half of the total $\mathrm{S}$ in standing dead S. alterniflora. This is possible, as there is a rapid loss of amino acids during the initial period of $S$, alterniflora decomposition (Buschbaum et al. 1991), and proteins are probably the major reservoir of organic S. Additionally, live plus dead fungal biomass may be 2 times greater than live fungal biomass (Newell 1992). Little is known about $\mathrm{S}$ content or potential peculiarities of $\mathrm{S}$ metabolism in fungi that are restricted to the saltmarsh environment. It is possible that salt marsh fungi could sequester relatively large quantities of $\mathrm{S}$, for example, as choline sulfate (Saggar et al. 1981) and perhaps as dimethyl sulfur compounds that could serve as osmolytes (Slaughter 1989, Pakulski \& Kiene 1992). Terrestrial fungi are known to respond to increases in ambient $\mathrm{S}$ concentrations (from 1 to $16 \mu \mathrm{g} \mathrm{S} \mathrm{ml}{ }^{-1}$ ) by increasing their sequestering of S by 2.6 times (Saggar et al. 1981). Seawater $S$ content is much greater (about $880 \mu \mathrm{g} \mathrm{ml}^{-1}$; Sverdrup et al. 1942) than the range used by Saggar et al. (1981).

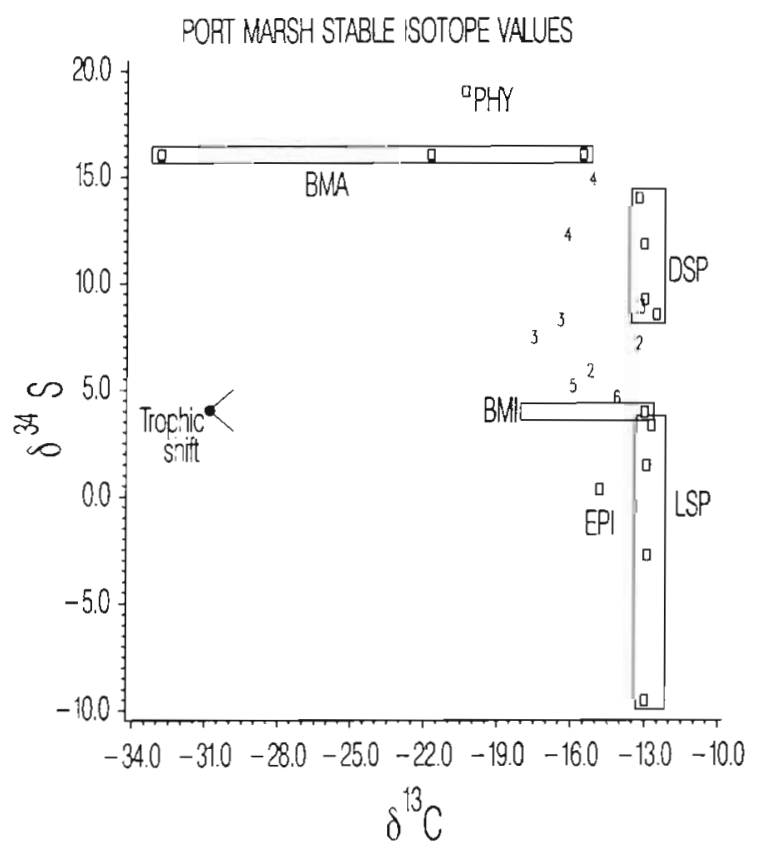

Fig. 2. Plot of $\delta \mathrm{C}^{13}$ vs $\delta^{34} \mathrm{~S}$ values for primary producers and consumers from Port Marsh, expressed as parts per mil $(\%)$. Primary producer groups include: PHY, phytoplankton ${ }_{i} B M A$, benthic macroalgae; BMI, benthic microalgae; EPI, epiphytic microalgae on standing dead Spartina alterniflora; LSP, live $S$. alterniflora; and DSP, standing dead S, alterniflora. Senescent $S$ alterniflora $\delta^{34} \mathrm{~S}$ values fell within the LSP box. Consumers include: llyanassa obsoleta, 2, Uca spp., 3, Littoraria irrorata, $4 ;$ Fundulus heteroclitus, 5; and F. majalis, 6 . S values for BMA and PHY are based on literature values; all other points are mean values from Tables $1 \& 2$. Boxes around primary producer groups illustrate the range of values for each group

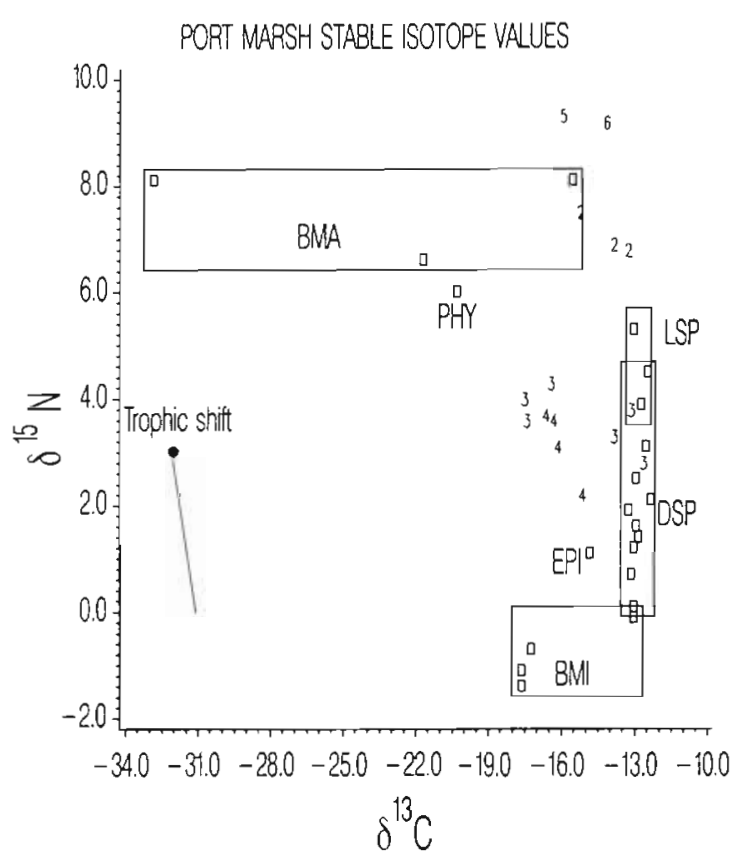

Fig. 3. Plot of $\delta \mathrm{C}^{13}$ vs $\delta^{15} \mathrm{~N}$ values for primary producers and consumers from Port Marsh, expressed as parts per mil (\%). PHY, phytoplankton; BMA, benthic macroalgae; BMI, benthic microalgae; EPI, epiphytic microalgae on standing dead Spartina alterniflora; LSP, live S. alterniflora; and DSP, standing dead $S$. alterniflora. Senescent $S$. alterniflora $\delta^{15} \mathrm{~N}$ values fell within the LSP box. Consumers include: Ilyanassa obsoleta, 2; Uca spp., 3; Littoraria irrorata, 4; Fundulus heteroclitus, 5; and $F$, majalis, 6 . Points are mean values from Tables 1 \& 2. Boxes around primary producer groups illustrate the range of values for each group

\section{Port Marsh food webs}

Dual isotope plots are frequently employed to examine trophic relationships between primary producers and consumers. Results for Port Marsh are plotted as $\delta^{13} \mathrm{C}$ vs $\delta^{34} \mathrm{~S}$ (Fig. 2) and $\delta^{13} \mathrm{C}$ vs $\delta^{15} \mathrm{~N}$ (Fig. 3). The vectors in these plots illustrate the direction and magnitude of shifts in the stable isotopic ratio of $\mathrm{C}, \mathrm{N}$, or $\mathrm{S}$ in assimilation by consumer organisms. The trophic shift in $\mathrm{C}$ and $\mathrm{S}$ assimilation is small, usually $\pm 1 \%$ (DeNiro \& Epstein 1978, Peterson \& Howarth 1987, Krouse et al. 1991), and thus animals should cluster near their respective food source in $\delta^{13} \mathrm{C}$ vs $\delta^{34} \mathrm{~S}$ plots. Data from Port Marsh plotted in this fashion indicate that benthic microalgae and standing dead Spartina alterniflora are important dietary components of Uca spp., Ilyanassa obsoleta, and Littoraria irrorata (Fig. 2). Fundulus spp., which are second level consumers, have the lightest $\delta^{34} \mathrm{~S}$ values, suggesting a discrimination against ${ }^{34} \mathrm{~S}$ in faunal assimilation. $L$. irrorata, which grazes on standing dead shoots and the marsh surface, and attains densities of over 100 ind. 
$\mathrm{m}^{-2}$ of marsh (Newell et al. 1989), exhibits the heaviest faunal $\delta^{34} \mathrm{~S}$ values. This provides indirect evidence of ${ }^{34} \mathrm{~S}$ enrichment in fungal biomass, as $L$. irrorata selectively ingest fungal biomass from standing dead S. alterniflora (Newell \& Barlocher 1993).

The $\delta^{13} \mathrm{C}$ vs $\delta^{15} \mathrm{~N}$ plot (Fig. 3) also provides strong evidence for the importance of benthic microalgae and standing dead Spartina alterniflora in the Port Marsh food web, and the potential importance of $\mathrm{N}_{2}$-fixing microorganisms. As illustrated by the vector in Fig. 3, the trophic shift in $\mathrm{N}$ assimilation is usually 2 to $4 \%$ (DeNiro \& Epstein 1981). It appears that benthic microalgae and standing dead $S$. alterniflora may be the primary dietary components of Uca spp. and Littoraria irrorata. The low $\delta^{15} \mathrm{~N}$ values for these organisms virtually rule out a significant dietary contribution from phytoplankton, live S. alterniflora, or benthic macroalgae.

The fiddler crabs Uca pugnax and U. pugilator are among the most abundant macroinvertebrates in salt marshes along the Atlantic coast. Both crabs are omnivores and ingest vascular plant detritus and associated microbes, benthic microalgae, and sediment grains (Montague 1980). U. pugilator is found on sandier sediments and has a lower $\delta^{15} \mathrm{~N}$ than $U$. pugnax, which is found in muddy sediments. The lower $\delta^{15} \mathrm{~N}$ value of $U$. pugilator may be due to the relatively high abundance of $\mathrm{N}_{2}$-fixing cyanobacteria in sandy areas of the marsh (Carpenter et al. 1978, Currin et al. in press). Previously, the trophic importance of $\mathrm{N}_{2}$-fixing microorganisms has been demonstrated with evidence from stable isotope analysis in a salt marsh (Peterson et al. 1985) and in other marine ecosystems (Fry et al. 1983, Pulich \& Scalan 1987).

Fundulus heteroclitus, the marsh killifish, is an abundant predator in southeastern estuaries and feeds on the salt marsh surface during periods of submergence. Its primary prey items are the fiddler crab Uca pugnax, polychaetes, and other small crustaceans (Kneib et al. 1980). The $C, N$, and $S$ isotope values of animals collected from Port Marsh were similar to values reported for other specimens analyzed from Georgia and North Carolina marshes, but were different from values reported from a Massachusetts salt marsh (Tables 2 \& 3). F. majalis, the longnose killifish, prefers sandy substrates and, although absent from the natural marsh, was abundant in the transplanted marsh. The $\delta^{13} \mathrm{C}$ of $F$. majalis in the transplanted marsh was heavier than that reported for specimens from a Mississippi marsh, and the $\delta^{34} \mathrm{~S}$ values were lighter (Sullivan \& Moncreiff 1990; see Table 3). However, Port Marsh F. majalis had similar $\delta^{15} \mathrm{~N}$ values to those reported in Mississippi (Table 3). Based on Port Marsh and literature $\mathrm{C}$ and $\mathrm{N}$ isotope values, it appears that both predatory Fundulus spp. could ultimately rely on benthic microalgal and standing dead Spartina alterniflora production.

Ilyanassa obsoleta, the marsh mud snail, is found in the lower intertidal region of salt marshes. It is a deposit feeder and can attain densities of over 500 to 1000 ind. $\mathrm{m}^{-2}$ (Pace et al. 1979, authors' pers. obs.). I. obsoleta can exist on an algal diet, and at natural densities, its grazing activity can significantly reduce microalgal biomass and productivity (Pace et al. 1979). It is unknown whether the relative enrichment in ${ }^{15} \mathrm{~N}$ in I. obsoleta, relative to the other grazers examined, is due to greater assimilation of animal tissue, or from grazing plant material with a heavier $\delta^{15} \mathrm{~N}$ value. The $\delta^{15} \mathrm{~N}$ of subtidal sediment was $1.8 \%$ heavier than that of upper intertidal sediment (Table 1), and so $I$. obsoleta's position in the lower intertidal zone may contribute to its heavier $\mathrm{N}$ isotope value

\section{Standing dead Spartina alterniflora and benthic microalgae in estuarine food webs}

Most previous studies utilizing a stable isotope approach to salt marsh food webs have used the isotopic signature of live Spartina alterniflora tissue as an end member in calculations of food web isotopic mass balance (Haines 1976. Haines \& Montague 1979, Peterson et al. 1986, Peterson \& Howarth 1987, Deegan et al. 1990, Sullivan \& Moncreiff 1990). The data presented here demonstrate that the $\delta^{15} \mathrm{~N}$ and $\delta^{34} \mathrm{~S}$ values of standing dead $S$. alterniflora are distinct from the isotopic values of live $S$. alterniflora, while the $\delta^{13} \mathrm{C}$ value of standing dead tissue is similar to that of live tissue (Fig. 1j. A comparison of the stable isotopic composition of fauna from Great Sippiwisset marsh, where ice pushes $S$. alterniflora onto the marsh surface during winter, to fauna from ice-free Sapelo Island marsh may illustrate the importance of incorporating the isotopic value of aerially decomposed $S$. alterniflora into salt marsh food web models. Peterson \& Howarth (1987) reported that fauna from Sapelo Island had $\delta^{34} \mathrm{~S}$ values that were $6 \%$ heavier than fauna from the Sippiwisset marsh. This difference is not entirely explained by the $3 \%$ difference in live $S$. alterniflora tissue between the 2 marshes (Peterson \& Howarth 1987), but is consistent with the utilization of ${ }^{34} \mathrm{~S}$-enriched standing dead $S$. alterniflora in the southern marsh. It is clear that using the isotopic values of standing dead $S$. alterniflora in food web analyses will provide a different picture of the importance of $S$. alterniflora as a food resource (Fig. 2).

In order to illustrate this point, stable $\mathrm{C}, \mathrm{N}$, and $\mathrm{S}$ isotope values were compiled from the literature for Spartina alterniflora and estuarine microalgae, macroalgae, and phytoplankton, and for the faunal species 
sampled in this study (Table 3). The values for $S$. alterniflora are restricted to samples from the East or Gulf coasts of North America. Phytoplankton values are from East Coast estuaries, except those for planktonic cyanobacterial blooms in the Gulf of Mexico which are included for comparative purposes. Benthic macroalgal isotopic values are from samples collected worldwide, to demonstrate that the wide range in $\delta^{13} \mathrm{C}$ values from the Port Marsh is representative of the situation in many environments (Tables $1 \& 3$ ). Benthic microalgal isotopic values include 8 previous reports of salt marsh microalgae. In addition, we have included isotopic values of benthic microalgae from other intertidal estuarine environments, including several cyanobacterial mats (Table 3). Isotopic values for selected salt marsh macrofauna and meiofauna are also restricted to published values from the Atlantic and Gulf coasts of North America.

Living Spartina alterniflora tissue has a fairly narrow range of $\delta^{13} \mathrm{C}$ values, and as demonstrated in this study, standing dead $S$. alterniflora has a $C$ isotopic signature similar to that of live tissue (see Figs. $1 \& 5$ ).

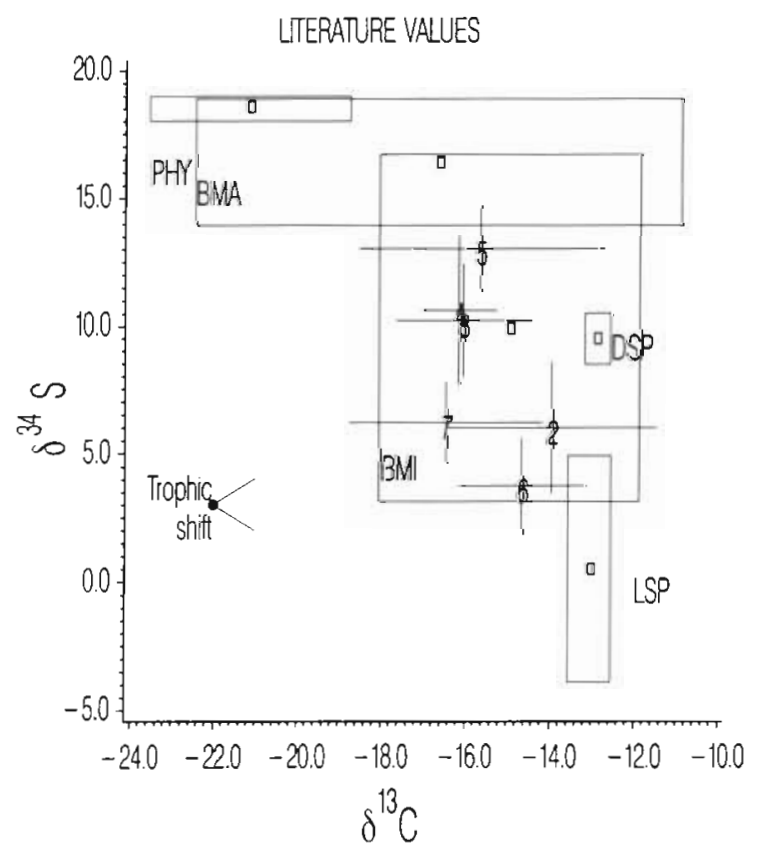

Fig. 4. Plot of $\delta \mathrm{C}^{13}$ vs $\delta^{34} \mathrm{~S}$ values for primary producers and consumers from literature values assembled in Table 3 , expressed as parts per mil (\%). Primary producer groups include: PHY, phytoplankton; BMA, benthic macroalgae; BMI, benthic microalgae; LSP, live and senescent Spartina alterniflora; and DSP, standing dead S. alterniflora. The large boxes around each primary producer represent the standard error of the mean value (small box) from Table 3 . Consumers include: Ilyanassa obsoleta, 2; Uca pugnax, 3; U. pugilator, 4; Littoraria irrorata, 5; Fundulus heteroclitus, 6 ; and $F$. majalis, 7 . Error bars for faunal values represent the standard error of the mean

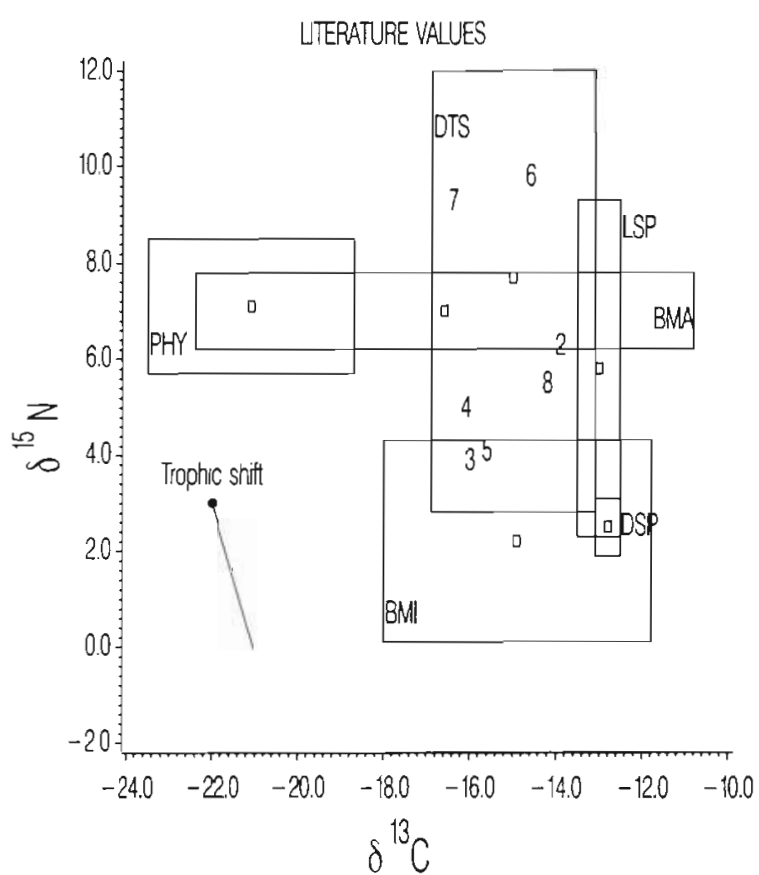

Fig. 5. Plot of $\delta \mathrm{C}^{13}$ vs $\delta^{15} \mathrm{~N}$ values for primary producers and consumers from literature values assembled in Table 3 , expressed as parts per mil $(\%)$. Primary producer groups include: PHY, phytoplankton; BMA, benthic macroalgae; $B M I$, benthic microalgae; LSP, live and senescent Spartina alterniflora; DSP, standing dead S. alterniflora, and DTS, sedimentary detrital $S$. alterniflora. The large boxes around each primary producer represent the standard error of the mean value (small box) from Table 3. Consumers include: llyanassa obsoleta, 2; Uca pugnax, 3; U. pugilator, 4; Littoraria irrorata, 5 ; Fundulus heteroclitus, 6 ; F. majalis, 7 ; and meiofauna, 8. Error bars around faunal values were excluded for clarity, however, these values are given in Table 3

The range in $\delta^{15} \mathrm{~N}$ values of live $S$, alterniflora is much larger $(1.6$ to $15.3 \%)$, and its mean $\delta^{15} \mathrm{~N}$ value $(5.8 \%$ ) is heavier than that $(2.5 \%)$ reported for standing dead S. alterniflora (Table 3). Standing dead S. alterniflora has a $\delta^{34} \mathrm{~S}$ value distinct from that of live $S$. alterniflora, and this shift places the box representing standing dead tissue in the dual isotope plot (Fig. 4) to a position distinct from live S. alterniflora. Similarly, the decrease in the $\delta^{15} \mathrm{~N}$ value places the box representing standing dead $S$. alterniflora in a dual isotope plot (Fig. 5) in a position removed from live $S$. alterniflora. In both cases, the shifts place standing dead $S$. alterniflora into a position that is more likely to represent a potential food source of the consumer organisms. However, it is clear from $\delta^{13} \mathrm{C}$ values that live or standing dead $S$. alterniflora cannot be the sole food resource of any of the consumers shown in these figures. Based on a $\delta^{13} \mathrm{C}$ of ca $-15 \%$, sedimentary S. alterniflora particles could be an important $C$ source for salt marsh consumer organisms (Fig, 5). Unfortunately, $\delta^{15} \mathrm{~N}$ values for sedi- 
mentary $S$, alterniflora detritus are few and disparate (Table 2), and $\delta^{34} \mathrm{~S}$ values are unavailable, so that the importance of this detrital fraction remains difficult to determine

To our knowledge, benthic macroalgae (e.g. Ulva sp.) have never been included on a published salt marsh dual isotope plot. The range in $\mathrm{N}$ and $\mathrm{S}$ isotopic values of benthic macroalgae are relatively narrow and overlap reported $\mathrm{N}$ and $\mathrm{S}$ values for phytoplankton. In contrast, the range in macroalgal $\delta^{13} \mathrm{C}$ is impressively large and has been well documented (Maberly et al. 1992). The box representing benthic macroalgal isotopic signatures intersects the range of probable food resources in Figs. 4 \& 5. Improved sample replication and additional study is required before the role of benthic macroalgae in salt marsh food webs can be determined with stable isotope analysis.

Phytoplankton are farther removed from consumer organisms than any other primary producer group in Figs. $4 \& 5$. It should be noted that most published values are from open estuarine waters rather than from within a salt marsh. As a source of isotopically light $\mathrm{C}$ to 'balance' the heavy $\mathrm{C}$ of Spartina alterniflora, phytoplankton have often been considered an important food resource in salt marsh food webs (Haines 1976. Haines \& Montague 1979, Peterson et al. 1986). Although phytoplankton undoubtedly play a role in the nutrition of many marsh consumers, Figs. $4 \& 5$ illustrate that many options besides a blend of phytoplankton and live $S$. alterniflora exist to explain the observed isotopic signature of marsh consumer organisms.

Port Marsh microalgal $\delta^{13} \mathrm{C}$ values obtained from July and September $(-13.0 \%,-14.8 \%)$ are heavier than previous reports of salt marsh benthic microalgae from food web studies (Haines 1976, Peterson \& Howarth 1987, Moncreiff \& Sullivan 1990), but are similar to other collections of salt marsh or mudflat microalgae (Schwinghamer et al, 1983, Couch 1989, see Table 3). The mean $\delta^{13} \mathrm{C}$ value of benthic microalgae collected in April (-17.5\%) is closer to the values of salt marsh benthic microalgae reported in previous salt marsh food web studies. Variation in the $\delta^{13} \mathrm{C}$ values of planktonic microalgae and marine macroalgae has been attributed to variations in the $\delta^{13} \mathrm{C}$ of dissolved inorganic carbon (DIC) due to photosynthesis and respiration, and to the physiological response of algae to DIC limitation (Fry \& Wainwright 1991, Fogel et al. 1992, Johnston \& Raven 1992, Simenstad et al. 1993). These conditions would be especially likely to occur at the sediment-water interface, where microalgal productivity and microbial respiration are high (DesMarais et al. 1989). Although the variation in the stable isotope composition of benthic algae has been recognized for years (Fry \& Sherr 1984), relatively few measurements of salt marsh microalgae have been made and the most frequently cited value $(-17 \%$, cf. Fry \& Sherr 1984) is lighter than the C isotopic composition of many salt marsh microalgae (Table 3). Based on reports of heavier $\delta^{13} \mathrm{C}$ values for pelagic cyanobacteria (Calder \& Parker 1973, Fry \& Sherr 1984) and benthic cyanobacteria (Calder \& Parker 1973, Pulich \& Scalan 1987, Des Marais et al. 1989; also see Table 3), $\delta^{13} \mathrm{C}$ values heavier than $-17 \%$ may be especially prevalent in environments where cyanobacteria make a significant contribution to microalgal biomass. A compilation of estuarine benthic microalgal stable isotopic values (Table 3 ) reveals an average of $-14.9 \%$ for the reported values. At a given site, a range in $\delta^{13} \mathrm{C}$ values can be due to both community composition (Pulich \& Scalan 1987) and to seasonal differences within a species (Schwinghamer et al. 1983).

There are much less data available for $\mathrm{N}$ and $\mathrm{S}$ isotopic values for benthic microalgae, and these numbers also exhibit a wide range (Table 3 ). The $\delta^{15} \mathrm{~N}$ values obtained for Port Marsh benthic and epiphytic microalgae are lower than values previously reported from salt marsh microalgal communities (Table 3). These values probably reflect an increased abundance of $\mathrm{N}_{2}$-fixing microorganisms (Currin et al. in press), and are most similar to $\delta^{15} \mathrm{~N}$ values from a cyanobacterial mat in Texas (Pulich \& Scalan 1987) and from another transplanted salt marsh in North Carolina (Craft et al. 1988; see Table 3 ). $\delta^{15} \mathrm{~N}$ values near zero may also result from isotopic fractionation during ammonium uptake (Wada \& Hattori 1991, Hoch et al. 1992), or from utilization of ${ }^{15} \mathrm{~N}$-depleted DIN (Paerl \& Fogel 1994).

The $\delta^{34} \mathrm{~S}$ values obtained for the Port Marsh benthic and epiphytic microalgae are lighter than what has previously been reported (Table 3). The benthic microalgal sample analyzed in this study was separated from the marsh sediment prior to analysis, and it might be expected that a sample that had presumably excluded inorganic sulfides might have a heavier $\delta^{34} \mathrm{~S}$ than a sample which contained sedimentary particles. Therefore, it is somewhat surprising that the benthic microalgal $\delta^{34} \mathrm{~S}$ values we obtained are lighter than the benthic microalgal $\delta^{34} \mathrm{~S}$ values reported by Peterson et al. (1986) and Sullivan \& Moncreiff (1990) for samples which were not isolated from sedimentary particles. The reasons for this discrepancy are unknown, and deserve further attention, as $\mathrm{S}$ isotopic values are critical in distinguishing primary producers with overlapping $C$ values (Peterson et al. 1985). The variations in the isotopic signatures of benthic microalgae point out the necessity of obtaining samples free from contaminating sediment or detritus, particularly in samples for $\mathrm{S}$ and $\mathrm{N}$ analysis, as the microalgal signal may be easily obscured by inorganic and detrital material. 
Sullivan \& Moncreiff (1990) used results from multiple stable isotope analysis as evidence of the importance of benthic algae in Mississippi salt marsh food webs. The C, N, and S isotope values from the Mississippi marsh are rather different from the mean values obtained from this study, and would fall closer to the box representing benthic macroalgae in Figs. 4 \& 5 . It is apparent that there is extreme variability in isotopic signatures possible from organisms occupying variable microhabitats. The fauna collected from Mississippi also had $C, N$, and $S$ values outside the norm (Table 3), and demonstrated as strong an indication of benthic algal utilization as do the Port Marsh faunal isotope values.

Based on the $\mathrm{C}$ vs $\mathrm{N}$ isotopic plot constructed with literature values (Fig. 5), it is apparent that given a presumptive $3 \%$ trophic shift in the $\delta^{15} \mathrm{~N}$ value of consumers (DeNiro \& Epstein 1981), either or both standing dead Spartina alterniflora and microalgae are an important source of $N$ in the diets of fiddler crabs, meiofauna, Littoraria irrorata, and the carnivorous Fundulus spp. This data includes isotope values from individuals collected in salt marshes from Nova Scotia to Mississippi (Table 3 ). Both $C$ vs $S$ and $C$ vs $N$ plots (Figs. $4 \& 5$ ) suggest that microalgae could be the sole food source of $U_{C a}$ spp. and that standing dead $S$. alterniflora detritus is a more likely secondary component of $U_{C a}$ spp. diets than phytoplankton, macro algae, or living $S$. alterniflora tissue (Figs. $4 \& 5$ ).

The data presented in this paper demonstrate that measures of the isotopic composition of naturally occurring Spartina alterniflora detritus are required to fully evaluate the role of $S$. alterniflora in food web studies. In the North Carolina marsh we examined, benthic microalgae and detrital $S$. alterniflora are important food resources. A wide range in benthic microalgal $C, N$, and $S$ isotopic values is reported in the literature, and future studies should include seasonal analyses of this potentially important part of estuarine food webs.

Acknowledgements. This work was supported by a grant from the NOAA Coastal Ocean Program. We thank H. Garrett, R. Michener, and B. Fry for help with the stable isotope analyses, and $C$. Lund for help with sample collection. We are grateful to E. Canuel, B. Fry, M. Sullivan, and G. Thayer for valuable comments on the manuscript.

\section{LITERATURE CITED}

Benner R, Fogel ML, Sprague EK, Hodson RE (1987) Depletion of ${ }^{13} \mathrm{C}$ in lignin and its implications for stable carbon isotope studies. Nature 329:708-710

Buschbaum R, Valiela I, Swain T, Dzierzeski M, Allen S (1991) Available and refractory nitrogen in detritus of coastal vascular plants and macroalgae. Mar Ecol Prog Ser 72: $131-143$
Calder JA, Parker PL (1973) Geochemical implications of induced changes in $\mathrm{C}^{13}$ fractionation by blue-green algae. Geochim Cosmochim Acta 37:133-140

Carlson PR, Forrest J (1982) Uptake of dissolved sulfide by Spartina alterniflora: evidence from natural sulfur isotope abundance ratios. Science 216:633-635

Carpenter EJ, Van Raalte CD, Valiela I (1978) Nitrogen fixation by algae in a Massachusetts salt marsh. Limnol Oceanogr 23:318-327

Cifuentes LA, Fogel ML, Pennock JR, Sharp JH (1989) Biogeochemical factors that influence the stable nitrogen isotope ratio of dissolved ammonium in the Delaware Estuary. Geochim Cosmochim Acta 53:2713-2721

Cifuentes LA, Sharp JH, Fogel ML (1988) Stable carbon and nitrogen isotope biogeochemistry in the Delaware estuary. Limnol Oceanogr 33:1102-1115

Couch CA (1989) Carbon and nitrogen stable isotopes of meiobenthos and their food resources. Estuar coast Shelf Sci 28:433-441

Craft CB, Broome SW, Seneca ED, Showers WJ (1988) Estimating sources of soil organic matter in natural and transplanted estuarine marshes using stable isotopes of carbon and nitrogen. Estuar coast Shelf Sci 26:633-641

Currin CA (1994) $\mathrm{N}_{2}$-fixation associated with detrital Zostera marina and standing dead Spartina alterniflora. PhD thesis, University of North Carolina, Chapel Hill

Currin CA, Joye SB, Paerl HW (1995) Diel rates of $\mathrm{N}_{2}$ fixation and denitrification in a transplanted Spartina alterniflora marsh: implications for N flux dynamics. Estuar coast Shelf Sci (in press)

Dacey JW, King GM, Wakeham SG (1987) Factors controlling emission of dimethylsulphide from salt marshes. Nature 330:643-645

Deegan L, Peterson BJ, Porter R (1990) Stable isotopes and cellulase activity as evidence for detritus as a food source for juvenile Gulf menhaden. Estuaries 13:14-19

DeNiro MJ, Epstein S (1978) Influence of diet on the distribution of carbon isotopes in animals. Geochim Cosmochim Acta 42:495-506

DeNiro MJ, Epstein S (1981) Influence of diet on the distribution of nitrogen isotopes in animals. Geochim Cosmoschim Acta 45:341-351

Des Marais DJ, Cohen Y, Nguyen $H$, Cheatham M, Cheatham T, Munoz E (1989) Carbon isotopic trends in the hypersaline ponds and microbial mats at Guerrero Negro, Baja California Sur, Mexico: implications for Precambrian stromatolites. In: Cohen Y, Rosenberg E (eds) Microbial mats: physiological ecology of benthic microbial communities. American Society for Microbiology, Washington, DC, p 191-203

Ember LM, Williams DF, Morris JT (1987) Processes that influence carbon jsotope variations in salt marsh sediments. Mar Ecol Prog Ser 36:33-42

Faganeli J, Vukovic A, Saleh FI, Pezdic J (1986) C:N:P ratios and stable carbon and hydrogen isotopes in the benthic marine alga; Ulva rigida C. Ag. and Fucus virsoides J. Ag. $J$ exp mar Biol Ecol 102:153-166

Fogel ML, Cifuentes LA, Velinsky DJ, Sharp JH (1992) Relationship of carbon availability in estuarine phytoplankton to isotopic composition. Mar Ecol Prog Ser 82:291-300

Fogel ML, Sprague EK, Gize AP, Frey RW (1989) Diagenesis of organic matter in Georgia salt marshes. Estuar coast Shelf Sci 28:211-230

Fry B, Lutes R, Northam M, Parker PL, Ogden J (1982a) A ${ }^{13} \mathrm{C} /{ }^{12} \mathrm{C}$ comparison of food webs in Caribbean seagrass meadows and coral reefs. Aquat Bot 14:389-398

Fry B, Scalan RS, Parker PL $(1983){ }^{13} \mathrm{C} /{ }^{12} \mathrm{C}$ ratios in marine 
food webs of the Torres Strait, Queensland. Aust J mar Freshwat Res 34:707-715

Fry B, Scalan RS, Winters JK, Parker PL (1982b) Sulphur uptake by salt grasses, mangroves, and seagrasses in anaerobic sediments. Geochim Cosmochim Acta 46:1121-1124

Fry B, Sherr EB $(1984){ }^{13} \mathrm{C}$ measurements as indicators of carbon flow in marine and freshwater ecosystems. Contrib mar Sci 27:13-47

Fry B, Wainwright SC (1991) Diatom sources of ${ }^{13} \mathrm{C}$-rich carbon in marine food webs. Mar Ecol Prog Ser 76:149-157

Griffin DH (1981) Fungal physiology. Wiley-lnterscience, New York

Hackney CT, Haines EB (1980) Stable carbon isotope composition of fauna and organic matter collected in a Mississippi estuary. Estuar coast mar Sci 10:703-708

Haddad RI, Newell SY, Martens CS, Fallon RD (1992) Early diagenesis of lignin-associated phenolics in the salt marsh grass Spartina alterniflora. Geochim Cosmochim Acta 56: $3751-3764$

Haines EB (1976) Stable carbon isotope ratios in the biota, soils and tidal water of a Georgia salt marsh. Estuar coast mar Sci 4:609-616

Haines EB, Montague CL (1979) Food sources of estuarine invertebrates analyzed using ${ }^{13} \mathrm{C} /{ }^{12} \mathrm{C}$ ratios. Ecology $60: 48-56$

Hamilton SK, Lewis WM Jr, Sippel SJ (1992) Energy sources for aquatic animals in the Ornoco River floodplain: evidence from stable isotopes. Oecologia 89:324-330

Hoch MP, Fogel ML, Kirchman DL (1992) Isotope fractionation associated with ammonium uptake by a marine bacterium. Limnol Oceanogr 37:1447-1459

Hodson RE, Christian RR, Maccubbin AE (1984) Lignocellulose and lignin in the salt marsh grass Spartina alterniflora: initial concentrations and short-term, postdepositional changes in detrital matter. Mar Biol 81:1-7

Howarth RW, Giblin AE (1983) Sulfate reduction in the salt marshes at Sapelo Island, Georgia. Limnol Oceanogr 28:70-82

Incze LS, Mayer LM, Sherr EB, Macko SE (1982) Carbon inputs to bivalve mollusks: a comparison of two estuaries. Can J Fish Aquat Sci 39:1348-1352

Johnston AM, Raven JA (1992) Effect of aeration rates on growth rates and natural abundance ${ }^{13} \mathrm{C} /{ }^{12} \mathrm{C}$ ratio of Phaeodactylum tricornutum. Mar Ecol Prog Ser 87:295-300

Kneib RT, Stiven AE, Haines EB (1980) Stable carbon isotope ratios in Fundulus heterocitus (L.) muscle tissue and gut contents from a North Carolina Spartina marsh. J exp mar Biol Ecol 46:89-98

Krouse HR, Stewart JWB, Grinenko VA (1991) Pedosphere and biosphere. In: Krouse HR, Grinenko VA (eds) Stable isotopes in the assessment of natural and anthropogenic sulphur in the environment. SCOPE 43. John Wiley \& Sons, Ltd, New York, p 267-306

Maberly C, Raven JA, Johnston AM (1992) Discrimination between ${ }^{12} \mathrm{C}$ and ${ }^{13} \mathrm{C}$ by marine plants. Oecologia 91 481-492

Mariotti A, Letolle R, Sherr E (1983) Distribution of stable nitrogen isotopes in a salt marsh estuary. Estuaries 6: 304-305

Montague CL (1980) A natural history of temperate western Atlantic fiddler crabs (genus Uca) with reference to their impact on the salt marsh. Contrib mar Sci 23:25-55

Newell SY (1992) Estimating fungal biomass and productivity in decomposing litter. In: Carroll GC. Wicklow DT (eds) The fungal community, 2nd edn. Marcel Dekker, Inc, New York, p 521-561

Newell SY (1993) Decomposition of shoots of a saltmarsh grass: methodology and dynamics of microbial assem- blages. Adv microb Ecol 13:301-326

Newell SY, Barlocher F (1993) Removal of fungal and total organic matter from decaying cordgrass leaves by shredder snails. J exp mar Biol Ecol 171:39-49

Newell SY, Falion RD (1989) Litterbags, leaf tags, and decay of nonabscissed intertidal leaves. Can J Bot 67:2324-2327

Newell SY, Fallon RD, Miller JD (1989) Decomposition and microbial dynamics for standing, naturally positioned leaves of the salt-marsh grass, Spartina alterniflora. Mar Biol 101:471-481

Newell SY, Hopkinson CS, Scott L (1992) Patterns of nitrogenase activity (acetylent? reduction) associated with standing, decaying shoots of Spartina alterniflora. Estuar coast Shelf Sci 35:127-140

Nriagu JO, Rees CE, Mekhtiyeva VL, Lein AY, Fritz P, Drimme RJ, Pankina RG, Robinson RW, Krouse HR (1991) Hydrosphere. In: Krouse HR, Grinenko VA (eds) Stable isotopes: natural and anthropogenic sulphur in the environment. SCOPE 43. John Wiley and Sons, Ltd, New York, p 177-265

Pace ML, Shimmel S, Darley WM (1979) The effect of grazing by a gastropod, Nassarius obsoletus, on the benthic microbial community of a salt marsh mudflat. Estuar coast mar Sci 9:121-134

Paerl HW, Fogel ML (1994) Isotopic characterization of atmospheric nitrogen inputs as sources of enhanced primary production in coastal Atlantic Ocean waters. Mar Biol $119.635-645$

Pakulski JD. Kiene RP (1992) Foliar release of dimethylsulfoniopropionate from Spartina alterniflora. Mar Ecol Prog Ser 81:277-287

Peterson BJ, Howarth RW (1987) Sulfur, carbon, and nitrogen isotopes used to trace organic matter flow in the salt-marsh estuaries of Sapelo Island, Georgia. Limnol Oceanogr 32 $1195-1213$

Peterson BJ, Howarth RW, Garritt RH (1985) Multiple stable isotopes used to trace the flow of organic matter in estuarine food webs. Science 227:1361-1363

Peterson BJ, Howarth RW, Garritt RH (1986) Sulfur and carbon isotopes as tracers of salt-marsh organic matter flow. Ecology 67:865-874

Pinckney J, Zingmark RG (1993) Modelling intertidal benthic microalgal annual production in an estuarine ecosystem. J Phycol 29:396-407

Pomeroy LR, Darley WM, Dunn EL, Gallagher JL, Haines EB, Whitney DM (1981) Primary production. In: Pomeroy LR, Wiegert W (eds) Ecology of a salt marsh. Springer-Verlag, New York, p 39-67

Pulich WM, Scalan RS (1987) Organic carbon and nitrogen flow from marine cyanobacteria to semiaquatic food webs. Contrib mar Sci 30:27-37

Raven JA, Osmond CB (1992) Inorganic C acquisition processes and their ecological significance in inter- and sub-tidal macroalgae of North Carolina. Funct Ecol 6:41-47

Saggar S, Bettany JR, Stewart JWB (1981) Measurement of microbial sulfur in soil. Soil Biol Biochem 13:492-498

Schwinghamer P, Tan FC, Gordon DC Jr (1983) Stable carbon isotope studies on the Pecks Cove mudflat ecosystem in the Cumberland Basin, Bay of Fundy. Can J Fish Aquat Sci 40 (Suppl 1):262-272

Simenstad CA, Duggins DO, Quay PD (1993) High turnover of inorganic carbon in kelp habitats as a cause of $\delta^{13} \mathrm{C}$ variability in marine food webs. Mar Biol 116:147-160

Slaughter JC (1989) Sulphur compounds in fungi. In: Boddy L, Marchant R, Reads DJ (eds) Nitrogen, phosphorus and sulphur in fungi. Cambridge University Press, New York. p $91-105$ 
Stephenson RL, Tan FC, Mann KH (1986) Use of stable carbon isotope ratios to compare plant material and potential consumers in a seagrass bed and a kelp bed in Nova Scotia, Canada. Mar Ecol Prog Ser 30:1-7

Sullivan MJ, Moncreiff CA (1988a) Primary production of edaphic algal communities in a Mississippi salt marsh. J Phycol 24:49-58

Sullivan MJ, Moncreiff CA (1988b) An evaluation of the importance of algae and vascular plants in salt marsh food webs using stable isotope analyses. Mississippi-Alabama Sea Grant Consortium, Project No. R/LR-18, MASGP-88042, Ocean Springs, MS, $p$ 1-62

Sullivan MJ, Moncreiff CA (1990) Edaphic algae are an important component of salt marsh food-webs: evidence from multiple stable isotope analyses. Mar Ecol Prog Ser 62:149-159

Sverdrup HU, Johnson MW, Fleming RH (1942) The oceans, their physics, chemistry, and general biology. PrenticeHall, Englewood Cliffs, NJ

Thayer GW, Parker PL, LaCroix MW, Fry B (1978) The stable

This article was presented by B. \& E. Sherr (Senior Editorial Advisors), Corvallis, Oregon, USA carbon isotope ratio of some components of an eelgrass, Zostera marina, bed. Oecologia 35:1-12

Trust BA Fry B (1992) Stable sulphur isotopes in plants: a review. Plant Cell Environ 15:1105-1110

Wada E, Hattori A (1991) Nitrogen in the sea: forms, abundances, and rate processes. CRC Press, Boca Raton, FL

White DS, Howes BL (1994) Nitrogen incorporation into decomposing litter of Spartina alterniflora. Limnol Oceanogr 39:133-140

Wilson JO, Buschbaum R, Valiela I, Swain T (1986) Decomposition in salt marsh ecosystems: phenolic dynamics during decay of litter of Spartina alterniflora. Mar Ecol Prog Ser 29:177-187

Winner WE, Smith CL, Koch GW, Mooney HA, Bewley JE, Krouse HR (1981) Rates of emission of $\mathrm{H}_{2} \mathrm{~S}$ from plants and patterns of stable sulphur isotope fractionation. Nature 289:672-673

Zedler J (1980) Algal mat productivity: comparisons in a salt marsh. Estuaries 3:122-131

Manuscript first received: Apri 29, 1994

Revised version accepted: December 21, 1994 